Check for updates

Cite this: RSC Adv., 2017, 7, 33851

\section{Design, synthesis, in vitro and in vivo evaluation of tacrine-cinnamic acid hybrids as multi-target acetyl- and butyrylcholinesterase inhibitors against Alzheimer's disease $\uparrow$}

\begin{abstract}
Yao Chen, ${ }^{\text {abc }}$ Hongzhi Lin, ${ }^{e}$ Jie Zhu, ${ }^{e}$ Kai Gu, ${ }^{e}$ Qi Li, ${ }^{e}$ Siyu He, ${ }^{e}$ Xin Lu, ${ }^{e}$ Renxiang Tan, Yuqiong Pei, ${ }^{a}$ Liang Wu, ${ }^{\text {b }}$ Yaoyao Bian ${ }^{\star d}$ and Haopeng Sun (iD *e

Previously, we have reported tacrine-ferulic acid hybrids as multi-target cholinesterase inhibitors against Alzheimer's disease. However, the detailed structure-activity relationship (SAR), especially regarding the ferulic acid moiety, has yet to be elucidated. Herein we report the structural modification of the ferulic acid moiety, which is replaced by cinnamic acid with different substitutions. The target compounds are synthesized and evaluated for their in vitro cholinesterase inhibitory activities, inhibition of amyloid $\beta$ protein self-aggregation, cyto-protective effects against hydrogen peroxide and antiproliferative activity in PC-12 cells. The optimal compounds 35 and 36 are subsequently selected for in vivo assays. 36 shows much better performance in ameliorating the scopolamine-induced cognition impairment and less hepatotoxicity than tacrine. The compound serves as a good lead compound for further optimization.
\end{abstract}

Received 19th April 2017

Accepted 27th June 2017

DOI: $10.1039 / \mathrm{c} 7 \mathrm{ra0} 4385 f$

rsc.li/rsc-advances

\section{Introduction}

Alzheimer's disease (AD) is the most prevalent form of late-life mental failure in humans and it affects about $6 \%$ of the population aged over $65 .{ }^{1}$ It is estimated that more than 18 million people presently suffer from $\mathrm{AD}$, and the number is predicted to sharply increase to 70 million by $2050 .^{2}$ The cardinal features of $\mathrm{AD}$ include progressive memory impairment, disordered cognitive function, altered behavior such as depression, hallucination, delusion, and agitation, and a progressive decline in language function. ${ }^{3}$ So far, it is well accepted that $\mathrm{AD}$ is a multifactorial syndrome deriving from a complex array of neurochemical factors. During the process of AD, cholinergic neurons and synapses of the basal forebrain are selectively lost, causing cognitive impairment. ${ }^{4}$ These findings inspired several theories about $\mathrm{AD}$ pathogenesis, including cholinergic dysfunction, ${ }^{5}$ amyloid cascade, ${ }^{6}$ hyperphosphorylation of $\tau$ protein, ${ }^{7}$ cell cycle hypothesis, ${ }^{8}$ and brain-derived neurotrophic

${ }^{a}$ School of Pharmacy, Nanjing University of Chinese Medicine, Nanjing, 210023, China ${ }^{b}$ State Key Laboratory Cultivation Base for TCM Quality and Efficacy, Nanjing University of Chinese Medicine, Nanjing, 210023, China

cJiangsu Key Laboratory for Functional Substance of Chinese Medicine, Nanjing University of Chinese Medicine, Nanjing, 210023, China

${ }^{d}$ School of Nursing, Nanjing University of Chinese Medicine, Nanjing, 210023, China. E-mail:1691@163.com; Tel: +86-15952007562

${ }^{e}$ Department of Medicinal Chemistry, China Pharmaceutical University, Nanjing, 210009, China. E-mail: sunhaopeng@163.com; Tel: +86-25-85863169

$\dagger$ Electronic supplementary information (ESI) available. See DOI: $10.1039 / \mathrm{c} 7 \mathrm{ra} 04385 \mathrm{f}$ factor hypothesis. ${ }^{9}$ Additionally, oxidative stress, ${ }^{\mathbf{1 0}}$ free radical formation, ${ }^{11}$ metal dyshomeostasis, ${ }^{12}$ and mitochondrial dysfunction, ${ }^{13}$ are also reported to be tightly correlated to the development of $\mathrm{AD}$ by supplying an inflammatory microenvironmental condition. These theories increase understanding of the basic mechanism of $\mathrm{AD}$, and, also depict a more complex AD scenario.

The cholinergic hypothesis of the pathogenesis of $\mathrm{AD}$ asserts that dysfunction of cholinergic system, mainly decline of acetylcholine (ACh) level, results in the cognitive and memory deficits. Therefore, recovering cholinergic function is believed to be beneficial for the treatment of AD. ${ }^{14}$ Generally, ACh can be hydrolyzed by two types of cholinesterases (ChEs), namely acetylcholinesterase (AChE) and butyrylcholinesterase (BuChE). Although the elucidation of the pathophysiology of AD provides multiple potential drug targets for designing effective drugs, acetylcholinesterase inhibitors (AChEIs) still serve as the main therapeutic agents applied clinically for AD.

The enzymatic site of human AChE is a narrow gorge with a length of approximate $20 \AA$, which contains two binding sites: the catalytic active site (CAS) at the bottom and the peripheral anionic site (PAS) near the entrance of the gorge. ${ }^{15,16}$ CAS is in charge of the hydrolysis of ACh and is consisted of key residues including Ser203, Glu334, and His447, which are referred to as the catalytic triad. ${ }^{17}$ PAS is composed of several aromatic residues such as Trp86, Trp286. ${ }^{18}$ It has been proved that PAS is closely related to both hydrolysis of ACh and neurotoxic cascade of $\mathrm{AD}$ through AChE-induced $\beta$-amyloid (A $\beta$ ) aggregation. ${ }^{19}$ Under normal condition, $\mathrm{AChE}$ is more active and can hydrolyze 
about $80 \%$ of ACh in human brains. ${ }^{20}$ However, both the level and the activity of $\mathrm{AChE}$ in $\mathrm{AD}$ patients are found to be remarkably reduced, leading to the compensative upregulation of BuChE, which further modulates the ACh levels. ${ }^{21}$ Therefore, inhibitors of both AChE and BuChE, such as tacrine and rivastigmine, are expected to exert potent therapeutic effect on $\mathrm{AD}$. Unfortunately, instead of curing or preventing the neurodegeneration, these drugs can only enable a palliative treatment. $^{22}$ Considering the multifactorial nature of $\mathrm{AD}$, the traditional agents designed by one-molecule one-target approach is insufficient to provide enough benefits. Thus, designing compounds that can simultaneously regulate multiple significant targets in the development of $\mathrm{AD}$, has emerged as a new strategy. These compounds, which are referred to as multi-target-directed ligands (MTDLs), ${ }^{23}$ are considered to offer additional properties other than cholinesterase inhibition. Substantial studies have been performed to achieve different types of MTDLs, many of which have been proved to show promising pharmacological effects on $\mathrm{AD}^{24-39}$ These results encourage medicinal chemists to continue this work. In recent years, designing MTDLs based on tacrine has attracted the attentions of medicinal chemists throughout the world and numerous related publications are disclosed to describe the efforts on this field. Compared to other AChEIs, tacrine is a good scaffold for the design of MTDLs due to its simple structure and high ligand efficiency (LE), which means tacrine can potently inhibit AChE with small number of nonhydrogen atoms. Moreover, tacrine has a good endurance against substantial structural modification while retaining the target-based activity, further provides a sound basis for the design of MTDLs. However, there is no newly approved small molecular agent for the treatment of $\mathrm{AD}$ in recent years, and most of the MTDLs remain at the stage of preclinical study. Therefore, it is still urgently needed for us to design new MTDLs and to fully understand the structural requirement through detailed structure-activity relationship (SAR) study.

Our group has been dedicated to the discovery of new MTDLs for nearly a decade. Previously, Fang L. et al. ${ }^{\mathbf{4 0}}$ and Chen Y. et $a .^{41}$ have disclosed a series of tacrine-ferulic acid hybrids as multifunctional potent ChEs inhibitors, most of which effectively inhibited ChEs in vitro in nanomolar range. These compounds were also proved to exert multiple functions, including antioxidant activities, vasorelaxation effects, and NOdonating behavior. In vivo studies by using the scopolamineinduced cognition impairment mouse model confirmed that these compounds can ameliorate the cognitive impairment and reduce the hepatotoxicity compared to the reference compound tacrine. These studies provided us promising lead compounds for further research. However, structural modification, especially on the ferulic acid moiety, is still limited and needs to be further elucidated. To deepen the understanding of the structural requirement for tacrine-ferulic acid hybrids, here we report the structural modification of ferulic acid moiety, which is replaced by cinnamic acid with different substitutions. The target compounds are synthesized and evaluated for their in vitro and in vivo activities related to the treatment of $\mathrm{AD}$, including in vitro assays for cholinesterase catalytic activity,
$\mathrm{A} \beta_{1-42}$ self-aggregation, cyto-protective effects against hydrogen peroxide and antiproliferative activity in PC-12 cells. Additionally, we also report the in vivo behavioral and hepatotoxic evaluations for the optimal compound selected from in vitro assays. Based on these results, we hope to supply more useful information of structure-activity relationship (SAR) that can guide further discovery of new MTDLs against AD.

\section{Results and discussions}

\section{Compound design and chemistry}

Compound CY-1, which was previously reported by our group, was used as the lead compound for structural modification. ${ }^{\mathbf{4 1}}$ The ferulic acid moiety of CY-1 was replaced by cinnamic acid with various substitutions at different positions of the phenyl ring (Fig. 1).

The synthesis of the tacrine-cinnamic acid hybrids is described in Fig. 1. Anthranilic acid (1) was condensed with cyclohexanone (2) to yield chloro acridine $3 .^{42}$ Treatment of 3 with ethane-1,2-diamine led to 4 , which was condensed with different cinnamic acid analogs (5-8-5-32) to result in the target compounds 8-32. Hydroxyl substituted cinnamic acids (5-33-536) were first protected with benzyl to obtain intermediates 633-6-36, whose benzyl ester moiety was subsequently hydrolyzed to result in 7-33-7-36. They were condensed with 4 to acquire target compounds 33-36. Reduction of the nitro group of 27-29 resulted in 37-39.

\section{Cholinesterase inhibitory activity and SAR analysis}

The inhibitory effects of the synthesized compounds against AChE from electrophorus electricus (eeAChE) and BuChE from equine serum (eqBuChE) were determined, following Ellman's method. ${ }^{43}$ The data were expressed as $\mathrm{IC}_{50}$ values (Table 1). Most of the compounds were proved to be potent inhibitors of ChEs, with $\mathrm{IC}_{50}$ values lower than $100 \mathrm{nM}$. The AChE $\mathrm{IC}_{50}$ value of 8, an analog without any substitution at the cinnamic acid moiety, was higher than most of the substituted ones. Methyl substitution (9-11) led to an increase of AChE inhibitory activity. The position of the methyl group was also considered, showing that the activity was para- > meta- > ortho-. Interestingly, 11 showed much improved activity on $\mathrm{AChE}\left(\mathrm{IC}_{50}=34.3\right.$ $\pm 1.8 \mathrm{nM}$ ), while its inhibitory effect on BuChE remarkably reduced $\left(\mathrm{IC}_{50}=86.9 \pm 6.6 \mathrm{nM}\right)$. When the methyl was replaced by a 4-methyl carbonate substitution (32), the compound exhibited a higher selectivity on AChE $\left(\mathrm{AChE} \mathrm{IC}_{50}=71.2 \pm\right.$

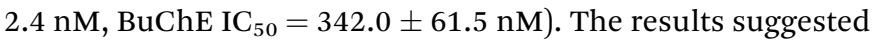
that bulky functional groups were well tolerated by AChE, while they were restricted by BuChE. Therefore, bulky groups at para-position can be a good choice to enhance the target selectivity on AChE. Next, we designed a series of methoxy group analogs to evaluate the impact of this group on activity. For mono-substituted compounds (12-19), the activity on AChE was para- > meta- > ortho-, the same to that of methyl analogs. Substitution of methoxy group at meta-position (13) seemed have no impact on the target selectivity $\left(\mathrm{AChE} \mathrm{IC}_{50}=\right.$ $47.4 \pm 2.0 \mathrm{nM}, \mathrm{BuChE} \mathrm{IC}_{50}=57.4 \pm 5.6 \mathrm{nM}$ ). It was noticeable 
when methoxy group was at ortho-position (12), it showed a 7.99-fold selectivity on BuChE $\left(\mathrm{AChE} \mathrm{IC}_{50}=123.8 \pm 7.6 \mathrm{nM}\right.$, BuChE $\left.\mathrm{IC}_{50}=15.5 \pm 1.5 \mathrm{nM}\right)$. Similar results were also observed on 9 with 2-methyl substitution $\left(\mathrm{AChE} \mathrm{IC}_{50}=80.6 \pm\right.$ $9.8 \mathrm{nM}$, BuChE $\mathrm{IC}_{50}=37.3 \pm 3.3 \mathrm{nM}$ ). We inferred that the shape difference of the binding site between AChE and BuChE led to such phenomenon. The binding site of AChE is narrow and long, while BuChE is broad and short. As a result, substitution at the ortho-position can lead to steric hindrance to the narrow binding site of AChE but was tolerated by BuChE. Oppositely, para-substitution resulted in the elongation of the molecular shape of the inhibitors, and was more suitable for the binding site of AChE. For multi-substituted compounds (15-19), we could also observe a trend that ortho-substitution (15 and 16) was preferred by BuChE, while para-substitution was better for AChE (19). Interestingly, for triOCH${ }_{3}$ analogs, 17 was very potent on both AChE and BuChE $\left(\mathrm{IC}_{50}=17.3 \pm 0.6\right.$ and $23.3 \pm 2.3 \mathrm{nM}$, respectively), while 18 showed considerably high selectivity on AChE.

Next, we evaluated the impact of halogen atoms on the ChEs activity. When substituted by $\mathrm{Cl}$ (20-22), the activity on AChE was para- > meta- > ortho-, while it showed an opposite manner on BuChE. The results were in accordance with those from methyl and methoxy group substitution. When substituted by different halogen atoms, the activity on AChE was $-\mathrm{Cl}(22) \approx$ $-\mathrm{Br}(\mathbf{2 4})>-\mathrm{F}(\mathbf{2 3})$. Meanwhile, the three compounds with parasubstitution were more selective on AChE than BuChE, a similar manner as mentioned above.

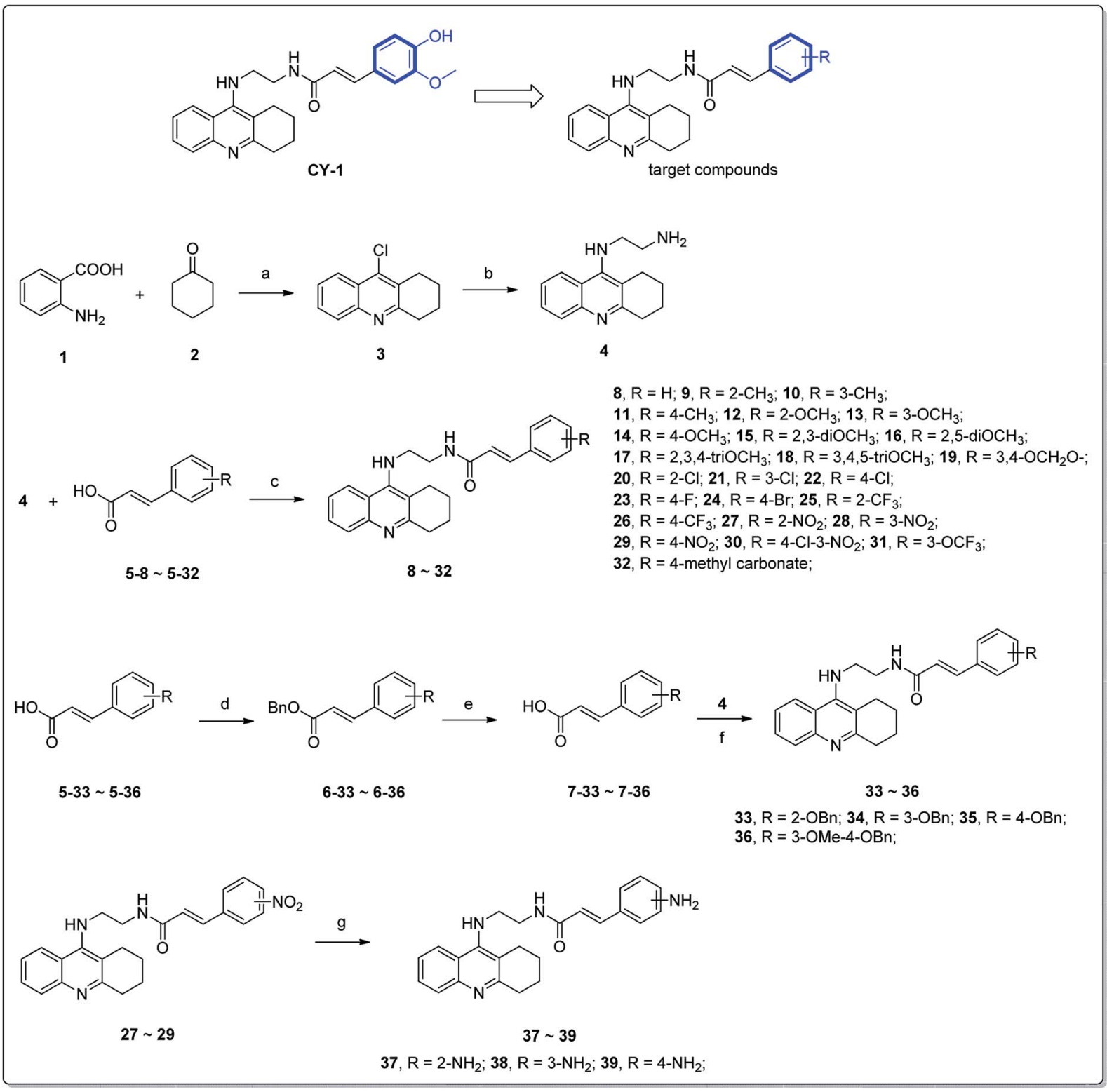

Fig. 1 Design strategy and synthetic route of the target compounds. Reagents and conditions: (a) $\mathrm{POCl}_{3}, \mathrm{reflux}, 3 \mathrm{~h}$; (b) pentanol, $\mathrm{NH}_{2}\left(\mathrm{CH}_{2}\right)_{2} \mathrm{NH}_{2}$, Nal, reflux, 18 h; (c) PyBop, DIPEA, anhydrous $\mathrm{CH}_{2} \mathrm{Cl}_{2}$, room temp, 24 h; (d) benzyl bromide, $\mathrm{K}_{2} \mathrm{CO}_{3}, \mathrm{DMF} ;(\mathrm{e}) \mathrm{NaOH}, \mathrm{MeOH}, \mathrm{H} \mathrm{O}, 5 \mathrm{~h}$; (f) $\mathrm{SnCl}_{2} \cdot 2 \mathrm{H}_{2} \mathrm{O}, \mathrm{EtOH}$, reflux, $8 \mathrm{~h}$. 
Then $-\mathrm{NO}_{2}(27-29)$ and $-\mathrm{CF}_{3}(25-26)$ and $-\mathrm{OCF}_{3}(31)$, three electron-withdrawing groups, were introduced as the $\mathrm{R}$ group. It was noteworthy that analogs with $-\mathrm{NO}_{2}$ substitution were the most active compounds on AChE among all the derivatives, with $\mathrm{IC}_{50}$ values in a single-digit nanomolar range. Meanwhile, they

Table 1 Inhibition of $\mathrm{AChE}$ and $\mathrm{BuChE}$ ( $\mathrm{IC}_{50}$ values), and selectivity expressed as the ratio of the resulting $I C_{50}$ values<smiles>[R]c1ccc(/C=C/C(=O)NCCNc2c3c(nc4ccccc24)CCCC3)cc1</smiles>

\begin{tabular}{|c|c|c|c|c|}
\hline \multirow[b]{2}{*}{ Cpd. } & \multirow[b]{2}{*}{$\mathrm{R}$} & \multicolumn{2}{|c|}{$\mathrm{IC}_{50}(\mathrm{nM}) \pm \mathrm{SEM}^{a}$} & \multirow[b]{2}{*}{$\mathrm{SI}^{f}$} \\
\hline & & $\mathrm{AChE}^{b}$ & $\mathrm{BuChE}^{c}$ & \\
\hline 8 & $\mathrm{H}$ & $92.5 \pm 6.9$ & $23.3 \pm 2.7$ & 4.0 \\
\hline 9 & $2-\mathrm{CH}_{3}$ & $80.6 \pm 9.8$ & $37.3 \pm 3.3$ & 2.2 \\
\hline 10 & $3-\mathrm{CH}_{3}$ & $78.9 \pm 2.3$ & $28.3 \pm 2.0$ & 2.8 \\
\hline 11 & $4-\mathrm{CH}_{3}$ & $34.3 \pm 1.8$ & $86.9 \pm 6.6$ & 0.4 \\
\hline 12 & $2-\mathrm{OCH}_{3}$ & $123.8 \pm 7.6$ & $15.5 \pm 1.5$ & 8.0 \\
\hline 13 & $3-\mathrm{OCH}_{3}$ & $47.4 \pm 2.0$ & $57.4 \pm 5.6$ & 0.8 \\
\hline 14 & $4-\mathrm{OCH}_{3}$ & $22.5 \pm 1.1$ & $61.3 \pm 4.3$ & 0.4 \\
\hline 15 & 2,3-diOCH 3 & $47.8 \pm 2.5$ & $23.2 \pm 3.1$ & 2.1 \\
\hline 16 & $2,5-\mathrm{diOCH}_{3}$ & $72.3 \pm 6.2$ & $26.1 \pm 4.5$ & 2.8 \\
\hline 17 & 2,3,4-triOCH 3 & $17.3 \pm 0.6$ & $23.3 \pm 2.3$ & 0.7 \\
\hline 18 & $3,4,5$-triOCH 3 & $20.3 \pm 0.5$ & $270.6 \pm 21.9$ & 0.1 \\
\hline 19 & $3,4-\mathrm{OCH}_{2} \mathrm{O}-$ & $49.3 \pm 2.5$ & $80.7 \pm 9.3$ & 0.6 \\
\hline 20 & $2-\mathrm{Cl}$ & $50.4 \pm 4.1$ & $19.4 \pm 1.4$ & 2.6 \\
\hline 21 & 3-Cl & $34.9 \pm 4.3$ & $21.8 \pm 1.4$ & 1.6 \\
\hline 22 & 4-Cl & $21.3 \pm 1.6$ & $39.1 \pm 3.7$ & 0.5 \\
\hline 23 & $4-\mathrm{F}$ & $68.6 \pm 5.7$ & $125.8 \pm 11.5$ & 0.6 \\
\hline 24 & $4-\mathrm{Br}$ & $27.4 \pm 1.7$ & $92.5 \pm 4.1$ & 0.3 \\
\hline 25 & $2-\mathrm{CF}_{3}$ & $52.1 \pm 1.5$ & $28.4 \pm 2.1$ & 1.8 \\
\hline 26 & $4-\mathrm{CF}_{3}$ & $33.0 \pm 1.3$ & $170.6 \pm 15.2$ & 0.2 \\
\hline 27 & $2-\mathrm{NO}_{2}$ & $7.1 \pm 0.5$ & $48.2 \pm 2.8$ & 0.2 \\
\hline 28 & $3-\mathrm{NO}_{2}$ & $3.8 \pm 0.1$ & $34.7 \pm 2.2$ & 0.1 \\
\hline 29 & $4-\mathrm{NO}_{2}$ & $6.8 \pm 0.7$ & $154.3 \pm 20.3$ & 0.0 \\
\hline 30 & $4-\mathrm{Cl}-3-\mathrm{NO}_{2}$ & $5.5 \pm 0.2$ & $64.4 \pm 5.4$ & 0.1 \\
\hline 31 & $3-\mathrm{OCF}_{3}$ & $56.5 \pm 1.7$ & $33.4 \pm 4.9$ & 1.7 \\
\hline 32 & 4-Methyl carbonate & $71.2 \pm 2.4$ & $342.0 \pm 61.5$ & 0.2 \\
\hline 33 & 2 -OBn & $103.2 \pm 9.9$ & $13.6 \pm 1.5$ & 7.6 \\
\hline 34 & 3-OBn & $40.1 \pm 1.2$ & $15.0 \pm 1.1$ & 2.7 \\
\hline \multirow[t]{2}{*}{35} & $4-\mathrm{OBn}$ & $29.5 \pm 1.0$ & $42.6 \pm 3.0$ & 0.7 \\
\hline & & $60.6 \pm 5.7^{d}$ & $86.1 \pm 15.5^{e}$ & 0.7 \\
\hline \multirow[t]{2}{*}{36} & 3-OMe-4-OBn & $15.8 \pm 0.7$ & $52.6 \pm 5.6$ & 0.3 \\
\hline & & $55.1 \pm 4.9^{d}$ & $55.9 \pm 3.3^{e}$ & 1.0 \\
\hline 37 & $2-\mathrm{NH}_{2}$ & $28.7 \pm 2.7$ & $18.7 \pm 2.2$ & 1.5 \\
\hline 38 & $3-\mathrm{NH}_{2}$ & $54.7 \pm 8.8$ & $115.2 \pm 12.5$ & 0.5 \\
\hline 39 & $4-\mathrm{NH}_{2}$ & $173.3 \pm 41.2$ & $68.5 \pm 7.9$ & 2.5 \\
\hline CY-1 & - & $62.0 \pm 10.5$ & $37.5 \pm 9.7$ & 1.7 \\
\hline Tacrine & - & $69.8 \pm 11.1$ & $10.6 \pm 1.1$ & 6.6 \\
\hline
\end{tabular}

${ }^{a}$ Concentration of the compound required for $50 \%$ inactivation of ChEs, data were shown in mean \pm SEM of three experiments. ${ }^{b}$ AChE (EC 3.1.1.7) from electric eel. ${ }^{c}$ BuChE (EC 3.1.1.8) from horse serum. ${ }^{d}$ AChE (EC 3.1.1.7) from human. ${ }^{e}$ BuChE (EC 3.1.1.8) from human.

${ }^{f}$ Selectivity index (SI) $=$ AChE IC $_{50} /$ BuChE IC $_{50}$.

\section{Lineweaver-Burk plot AChE inhibition by compound 36}

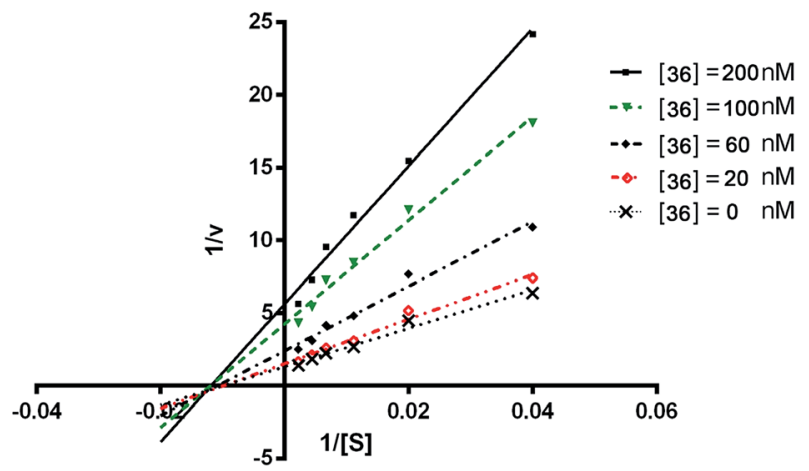

Fig. 2 Lineweaver-Burk plots resulting from subvelocity curves of huAChE activity with different substrate concentrations $(25-450 \mu \mathrm{M})$ in the absence and presence of 20,60,100, 200 nM 36.

all exhibited a remarkable selectivity toward AChE than BuChE $(\mathrm{SI}=0.04-0.15)$. The impact of $-\mathrm{CF}_{3}$ and $-\mathrm{OCF}_{3}$ was lower than $-\mathrm{NO}_{2}$, however, they also showed the same target selective rule to other groups mentioned above.

We subsequently introduced amino (37-39) as hydrogenbond donating group. We found that such groups resulted in a remarkably reduced activity on $\mathrm{AChE}\left(\mathrm{IC}_{50}=54.7 \pm 8.8-173.3\right.$ $\pm 41.2 \mathrm{nM}$ ) except 37, which was active toward both AChE and BuChE $\left(\mathrm{IC}_{50}=28.7 \pm 2.7,18.7 \pm 2.2 \mathrm{nM}\right.$, respectively). Considering the hydrophobic nature of the binding site, especially for AChE, introduction of polar substitutions may lead to the improper intermolecular recognition, thus reducing the activity. Inspired by this, we replaced the hydroxyl to benzyloxyl. The ortho-substitution (33) exhibited high selectivity on BuChE, while meta- (34) and para-substitution (35 and 36) were preferable to AChE. These results further suggested the steric hindrance of the groups on the target selectivity.

To further validated the inhibitory activities of synthesized compounds on human ChEs, the representative compounds, 35 and $\mathbf{3 6}$ were selected for determination (Table 1). 35 exhibited huAChE IC I0 $_{50}=60.6 \pm 5.6 \mathrm{nM}$, huBuChE IC $_{50}=86.1 \pm 15.5 \mathrm{nM}$; 36 exhibited huAChE $\mathrm{IC}_{50}=55.1 \pm 4.9 \mathrm{nM}$, huBuChE $\mathrm{IC}_{50}=$ $55.9 \pm 3.3 \mathrm{nM}$. The results showed that the synthesized compounds efficiently inhibited the activities of human ChEs, further confirmed their activities as ChEs inhibitors.

\section{Kinetic study of AChE inhibition}

To further analyze the binding manner of the synthesized compounds to huAChE, the potent inhibitor $\mathbf{3 6}$ was selected as

Table 2 The $V_{\max }$ and $K_{\mathrm{m}}$ values for compound 36 in kinetic studies. Data are shown in mean \pm SD of three experiments

\begin{tabular}{|c|c|c|c|}
\hline $\begin{array}{l}\text { Concentration } \\
\text { (nM) }\end{array}$ & $V_{\max }\left(\mu \mathrm{M} \min ^{-1}\right)$ & $K_{\mathrm{m}}(\mu \mathrm{M})$ & $R$ square \\
\hline 0 & $0.9 \pm 0.1$ & $147.8 \pm 18.8$ & 0.99 \\
\hline 5 & $0.8 \pm 0.0$ & $139.7 \pm 16.3$ & 0.99 \\
\hline 10 & $0.5 \pm 0.0$ & $145.9 \pm 22.4$ & 0.99 \\
\hline 15 & $0.3 \pm 0.0$ & $141.4 \pm 25.2$ & 0.99 \\
\hline 40 & $0.2 \pm 0.0$ & $148.7 \pm 27.5$ & 0.99 \\
\hline
\end{tabular}



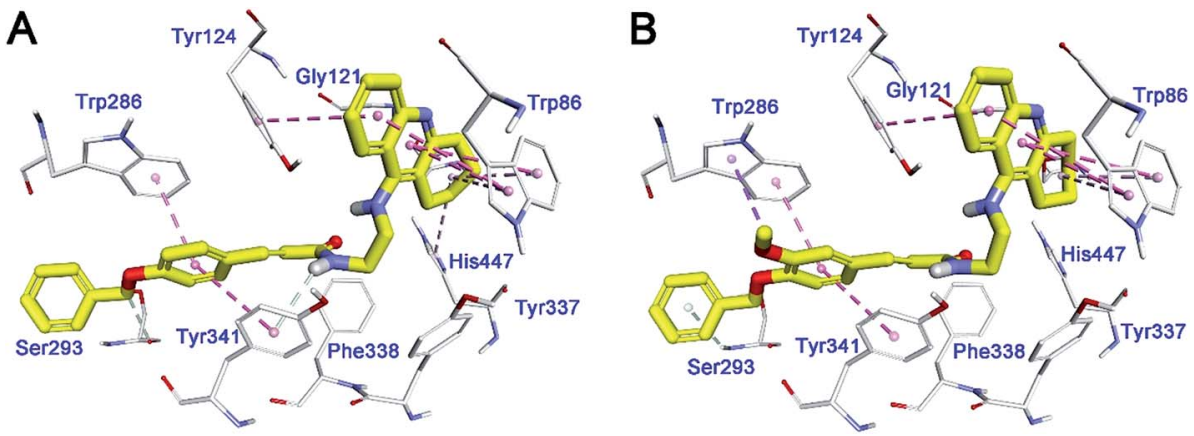

Fig. 3 Binding mode prediction of 35 (A), and 36 (B) with huAChE (PDB id: 4EY7). Compounds were shown in stick mode colored in yellow. Key residues were labeled as thin stick mode colored in white. Intermolecular interactions were shown as dot lines with different colors according to the type of the interaction: light green, hydrophobic contact; pink, $\pi-\pi$ stacking; purple, $\pi$-alkyl contact.

representative compound to perform the kinetic studies as described previously. ${ }^{34}$ Lineweaver-Burk reciprocal plots was applied to elucidate the type of inhibition of the test compounds. Briefly, Lineweaver-Burk plot can be described by reciprocal rates versus reciprocal substrate concentrations for the different inhibitor concentrations resulting from the substrate-velocity curves for ChEs. According to the results (Fig. 2), increasing concentration of the compounds $(20,60$, 100 , and $200 \mathrm{nM}$ ) resulted in both increased slopes (decreased $V_{\max }$ ) and intercepts (higher $K_{\mathrm{m}}$ ), indicating a mixed-type inhibition of 36. The detailed values of $V_{\max }$ and $K_{\mathrm{m}}$ at different concentrations are shown in Table 2.

\section{Molecular modeling studies}

To investigate the binding pattern of the synthesized compounds with huAChE, molecular docking studies were performed using Discovery Studio (DS). 35, and 36 were selected as representative compounds. As shown in Fig. 3A and B, both the compounds bound to AChE in a dual-site manner by occupying both CAS and PAS. The 1,2,3,4-tetrahydroacridin moiety of the two compounds inserted into the CAS. The tetrahydroacridin moiety formed multiple $\pi-\pi$ stacking contacts with the aromatic sidechains of Trp86 and Tyr124. These hydrophobic contacts provided driving force for the binding of the compounds to CAS of huAChE. The substituted phenyl ring of cinnamic acid moiety was located at the PAS of huAChE binding groove. ${ }^{44}$ It formed $\pi-\pi$ stacking contacts with the sidechain of Trp286, Tyr341. It was noticeable that the methoxy group at meta-position of the phenyl ring (36) formed an additional $\pi$-alkyl interaction with the sidechain of Trp286. The binding difference may explain the slightly better huAChE inhibitory activity of $\mathbf{3 5}$ than $\mathbf{3 6}$.

In summary, the binding mode of the selected compounds supported the mixed-type of binding manner revealed by the kinetic study.

\section{Inhibition of self-induced $A \beta_{1-42}$ aggregation}

All compounds were evaluated for their inhibitory capacity on self-induced $A \beta_{1-42}$ aggregation based on a thioflavin T-based fluorometric assay. Curcumin, a natural product that is known to inhibit the $A \beta_{1-42}$ self-aggregation, was used as the reference compound. Most of the analogs only showed poor or moderate inhibition on $\mathrm{A} \beta_{1-42}$ self-aggregation (ranging from $4.2 \pm 0.1-37.8 \pm 3.9 \%$, Table 3). Two compounds, 35, and 36, exhibited inhibitory rate over $40 \%(40.7 \pm 1.9,42.2 \pm 2.6 \%$, respectively). Interestingly, 36 was potent on both AChE and self-induced $A \beta_{1-42}$ aggregation, indicating its potential for acting as a multi-target compound. It seemed that a methyl group was preferred in inhibiting $A \beta_{1-42}$ self-aggregation, especially when substituted at the para-position. Larger groups such as $t$-Bu led to a greater than 2 -fold decrease in activity. Mono-substitution of methoxy group led to the completely loss of the inhibitory effect, however, di- or trisubstitution of methoxy groups $(\mathbf{1 6}, \mathbf{1 8}, \mathbf{1 9})$ supplied moderate

Table 3 Inhibition of self-induced $A \beta_{1-42}$ aggregation and antiproliferative activities of the synthesized compounds

\begin{tabular}{lrllrl}
\hline $\mathrm{Cpd}$. & $\mathrm{A} \beta \mathrm{IR}^{a} \%$ & $\mathrm{IC}_{50}{ }^{b}(\mu \mathrm{M})$ & $\mathrm{Cpd}$. & \multicolumn{1}{c}{$\mathrm{A} \beta \mathrm{IR}^{a} \%$} & $\mathrm{IC}_{50}{ }^{b}(\mu \mathrm{M})$ \\
\hline $\mathbf{8}$ & $7.0 \pm 0.6$ & $55.7 \pm 5.8$ & $\mathbf{2 4}$ & $21.6 \pm 3.6$ & $34.2 \pm 4.7$ \\
$\mathbf{9}$ & $33.2 \pm 0.8$ & $71.7 \pm 6.8$ & $\mathbf{2 5}$ & $7.0 \pm 0.1$ & $19.8 \pm 2.4$ \\
$\mathbf{1 0}$ & $32.9 \pm 2.1$ & $39.9 \pm 4.0$ & $\mathbf{2 6}$ & $22.4 \pm 1.7$ & $10.1 \pm 1.0$ \\
$\mathbf{1 1}$ & $40.9 \pm 1.6$ & $27.1 \pm 3.2$ & $\mathbf{2 7}$ & $6.0 \pm 0.8$ & $34.5 \pm 2.5$ \\
$\mathbf{1 2}$ & $4.2 \pm 0.1$ & $63.0 \pm 9.2$ & $\mathbf{2 8}$ & $5.6 \pm 0.2$ & $23.7 \pm 1.2$ \\
$\mathbf{1 3}$ & $8.4 \pm 0.6$ & $56.3 \pm 5.1$ & $\mathbf{2 9}$ & $13.6 \pm 1.2$ & $55.0 \pm 6.5$ \\
$\mathbf{1 4}$ & $7.9 \pm 0.9$ & $51.6 \pm 9.4$ & $\mathbf{3 0}$ & $19.4 \pm 2.8$ & $13.5 \pm 1.7$ \\
$\mathbf{1 5}$ & $5.1 \pm 0.2$ & $79.6 \pm 11.5$ & $\mathbf{3 1}$ & $30.0 \pm 5.1$ & $10.0 \pm 1.0$ \\
$\mathbf{1 6}$ & $34.5 \pm 2.3$ & $55.2 \pm 4.4$ & $\mathbf{3 2}$ & $17.6 \pm 1.3$ & $59.6 \pm 8.0$ \\
$\mathbf{1 7}$ & $21.4 \pm 3.8$ & $26.3 \pm 2.9$ & $\mathbf{3 3}$ & $40.7 \pm 1.9$ & $14.5 \pm 1.9$ \\
$\mathbf{1 8}$ & $28.8 \pm 4.0$ & $18.7 \pm 1.4$ & $\mathbf{3 4}$ & $35.9 \pm 2.1$ & $43.8 \pm 3.9$ \\
$\mathbf{1 9}$ & $31.3 \pm 4.0$ & $34.9 \pm 4.0$ & $\mathbf{3 5}$ & $37.8 \pm 3.9$ & $92.2 \pm 8.8$ \\
$\mathbf{2 0}$ & $30.1 \pm 2.7$ & $29.4 \pm 1.9$ & $\mathbf{3 6}$ & $42.2 \pm 2.6$ & $84.6 \pm 7.3$ \\
$\mathbf{2 1}$ & $28.9 \pm 2.1$ & $30.9 \pm 4.2$ & $\mathbf{3 7}$ & $19.9 \pm 0.3$ & $34.8 \pm 2.6$ \\
$\mathbf{2 2}$ & $35.3 \pm 3.8$ & $20.1 \pm 3.0$ & $\mathbf{3 8}$ & $14.4 \pm 1.0$ & $41.8 \pm 3.9$ \\
$\mathbf{2 3}$ & $22.7 \pm 2.9$ & $28.7 \pm 2.1$ & $\mathbf{3 9}$ & $25.1 \pm 3.1$ & $37.3 \pm 4.1$ \\
& & & Curcumin & $46.2 \pm 3.2$ & -
\end{tabular}

${ }^{a}$ IR stands for inhibitory rate. Inhibition of self-induced $A \beta_{1-42}$ aggregation was determined by thioflavin-T fluorescence method, and the data were shown in mean \pm SEM of three independent experiments. The experiments were performed in the presence of 20 $\mu \mathrm{M}$ target compounds. ${ }^{b}$ The antiproliferative activities of the target compounds on PC12 cells. The $\mathrm{IC}_{50}$ values were calculated based on three independent experiments and were shown in mean \pm SEM. 


\section{Protective effects against $\mathrm{H}_{2} \mathrm{O}_{2}$}

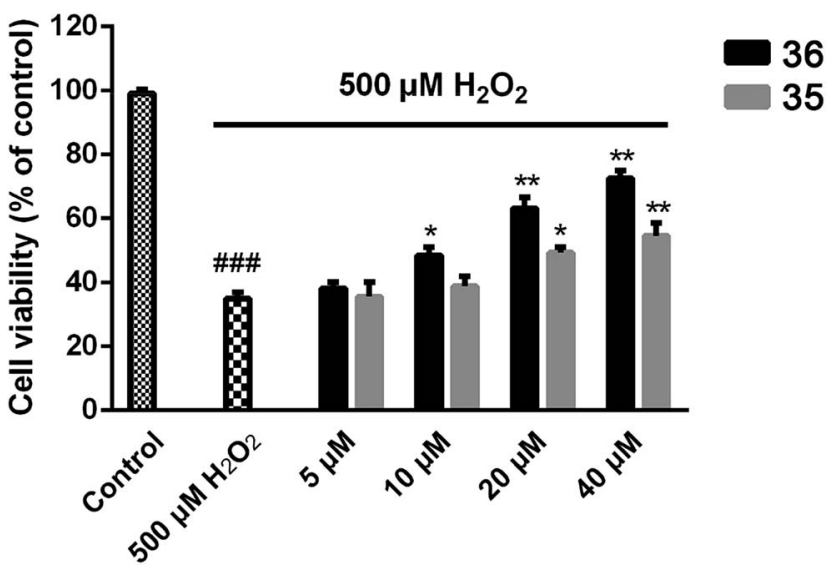

Fig. 4 Protective effects of compound 35 or 36 against $\mathrm{H}_{2} \mathrm{O}_{2}$-induced cell death in PC-12 cells. PC12 cells were plated in a 96-well plate for $12 \mathrm{~h}$ and then treated with various concentrations of 35 or 36 for another $24 \mathrm{~h}$. After replacing the medium containing $500 \mu \mathrm{M} \mathrm{H}_{2} \mathrm{O}_{2}$, incubation of the cells was continued for $12 \mathrm{~h}$, then the cell viability was measured by MTT assay. All data represent the means \pm SD of three independent experiments. Data were shown as mean $\pm \mathrm{SD}(n=$ 3). $p \# \# \#<0.001$ compared to control, $p^{*}<0.05, p^{* *}<0.01$ compared to $\mathrm{H}_{2} \mathrm{O}_{2}$-treated cells.

activity. Electron-withdrawing group, such as $-\mathrm{NO}_{2}$ and $-\mathrm{CF}_{3}$, remarkably reduced the activity. Substituent groups such as halogen, hydroxyl or amino group had no impact on the inhibition of $A \beta_{1-42}$ self-aggregation, no matter what position they were at. It was noticeable that benzyl substituted compounds (33-36) exhibited the best activity among all the derivatives, suggesting this benzyl group was not only important for AChE inhibition, but also acted as a preferred moiety for designing new MTDLs.

\section{Cell toxicity and cyto-protection effects of the compounds in} PC-12 neuroblastoma cells

We next focused on the cell toxicities of the synthesized compounds. They were evaluated for the anti-proliferative effects against neuroblastoma PC-12 cell line. Most of the synthesized compounds exhibited $\mathrm{IC}_{50}$ values above $30 \mu \mathrm{M}$ (Table 3). 35 and 36 showed the best safety on PC-12 cells ( IC $_{50}$ $=92.2 \pm 8.8 \mu \mathrm{M}$ and $84.6 \pm 7.3$, respectively). Considering their good inhibitory activity on ChEs and self-induced $\mathrm{A} \beta_{1-42}$ aggregation, especially 36, they were selected for further in vivo evaluations. It was noteworthy that the nitro-substituted compounds 27, 28, and 30 showed much stronger antiproliferative activity against PC-12 cells than most of the derivatives $\left(\mathrm{IC}_{50}=34.5 \pm 2.5,23.7 \pm 1.2,13.5 \pm 1.7 \mu \mathrm{M}\right.$, respectively), indicating their potential cytotoxicity. Although these nitro-substituted compounds showed the best inhibitory effects on AChE, they only exerted poor activity on self-induced $\mathrm{A} \beta_{1-42}$ aggregation. Taken together, these compounds were not investigated for their in vivo activity. Besides, $\mathrm{CF}_{3}$-substituted compounds 25 and 26 also potently inhibited the proliferation of PC-12 cells ( $\mathrm{IC}_{50}=19.8 \pm 2.4$ and $10.1 \pm 1.0 \mu \mathrm{M}$, respectively).
Although strong electron-withdrawing groups were preferred for AChE inhibition, it seemed that they were prone to cause a strong cytotoxicity. Similar manner was observed in $3-\mathrm{OCF}_{3}$ substituted analog $31\left(\mathrm{IC}_{50}=10.0 \pm 1.0 \mu \mathrm{M}\right)$. Highly toxic compounds also included 18, 22, and $33\left(\mathrm{IC}_{50}=18.7 \pm 1.4,20.1\right.$ \pm 3.0 , and $14.5 \pm 1.9 \mu \mathrm{M}$, respectively).

Then, we evaluated the cytoprotective effects of 35 and 36 on $\mathrm{H}_{2} \mathrm{O}_{2}$-induced cell damage. Treatment with $500 \mu \mathrm{M} \mathrm{H}_{2} \mathrm{O}_{2}$ for $24 \mathrm{~h}$ caused over $60 \%$ death rate of PC12 cells compared with the control group (Fig. 4). When pretreated with 35 and 36 for $24 \mathrm{~h}$, the mortality rate of PC-12 cells caused by $\mathrm{H}_{2} \mathrm{O}_{2}$ was significantly attenuated. Such protective effect exhibited dosedependent manner for both the two compounds. 36 showed a better cytoprotective effect than 35 . It increased the cell viability to $63.1 \pm 2.1 \%$ and $72.5 \pm 2.1 \%$ at the concentration of 20 and $40 \mu \mathrm{M}$, respectively. These results indicated that 36 had a potential in antagonizing the oxidative stress.

\section{Behavioral studies}

Improvement of cognitive ability is the most significant profile of anti-AD agents. Based on the multiple evaluations mentioned above, compound $\mathbf{3 6}$ with the best multipotent activity profile was selected for in vivo behavioral study by using a Morris water maze test. The animal model was built on the basis of scopolamine-induced cognition-impaired adult ICR mice and was applied for the cognitive improvement effects of $\mathbf{3 6}$. Compound 35 was also evaluated with the aim to understand the importance of the methoxy group. Tacrine $\left(20 \mu \mathrm{mol} \mathrm{kg} \mathrm{kg}^{-1}\right.$ body weight) was used as positive control. 35, 36, and tacrine were orally administered to the ICR mice $30 \mathrm{~min}$ before intraperitoneal (ip) administration of scopolamine $\left(1 \mathrm{mg} \mathrm{kg}^{-1}\right)$ or saline solution for 10 consecutive days to adapt the apparatus. The test included 5 days of learning and memory training and a probe trial on the sixth day. The mean escape latency values of all the groups on the sixth day were shown in Table 4 and Fig. 5A. Compared to the control group, scopolamine led to a remarkable delay of the latency to target $(8.9 \pm 4.0$ seconds $v s$. $45.2 \pm 11.6$ seconds), indicating that the cognitive impairment mouse model was successfully built. Treatment of tacrine ameliorated the impairment and the latency to target reduced to $36.3 \pm 11.6$ seconds $\left({ }^{*} p<0.05\right) .35$ exhibited a comparable activity to tacrine $\left(36.4 \pm 14.3\right.$ seconds, $\left.{ }^{*} p<0.05\right)$. Compared to tacrine and 35, 36 significantly reduced the latency to target

Table 4 Effects of oral administration of 35 and $36\left(15 \mathrm{mg} \mathrm{kg}^{-1}\right)$ on scopolamine-induced memory impairment in ICR mice evaluated by the Morris water maze test. Tacrine $\left(15 \mathrm{mg} \mathrm{kg}^{-1}\right)$ was used as positive control. Data are presented as the mean $\pm \operatorname{SEM}(n=6 ; * p<0.05, * * * p$ $<0.001, * * * * p<0.0001$ vs. scopolamine model group)

\begin{tabular}{lcc}
\hline Group & Latency to target $(\mathrm{s})$ & Distance to target $(\mathrm{cm})$ \\
\hline Control & $8.9 \pm 4.0$ & $292.8 \pm 206.4^{* * * * *}$ \\
Model & $45.2 \pm 11.6$ & $1637.3 \pm 517.1$ \\
Tacrine & $36.3 \pm 11.6^{*}$ & $1125.3 \pm 367.1$ \\
$\mathbf{3 6}$ & $13.2 \pm 7.6^{* * *}$ & $469.5 \pm 278.8^{* * * *}$ \\
$\mathbf{3 5}$ & $36.4 \pm 14.3^{*}$ & $1274.9 \pm 452.6$
\end{tabular}




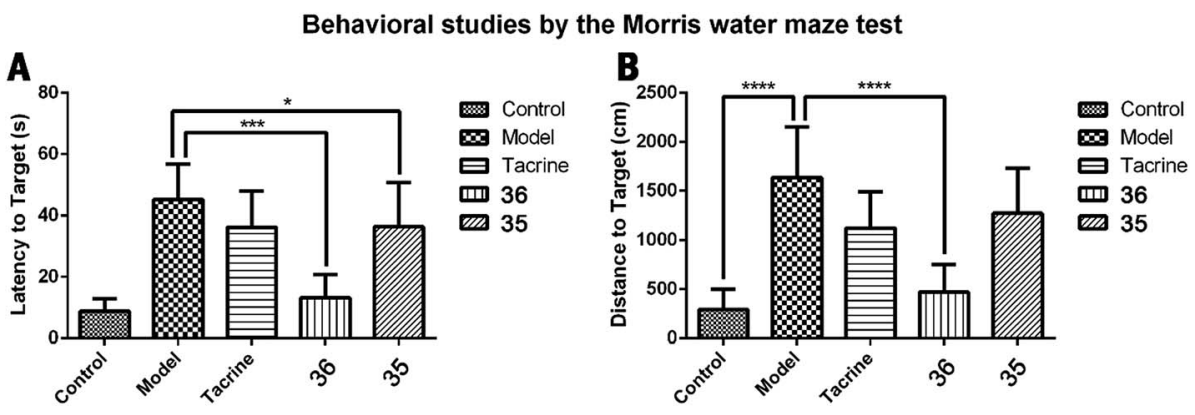

Fig. 5 Effects of oral administration of tacrine $\left(15 \mathrm{mg} \mathrm{kg}^{-1}\right), 35\left(15 \mathrm{mg} \mathrm{kg}^{-1}\right)$, and $36\left(15 \mathrm{mg} \mathrm{kg}^{-1}\right)$ on scopolamine-induced cognitive impairment in ICR mice determined by the Morris water maze test. (A) The latency to target; (B) the distance to target. Data are presented as the mean \pm SEM ( $n=6 ; * p<0.05, * * * p<0.001, * * * * p<0.0001$ vs. scopolamine group).

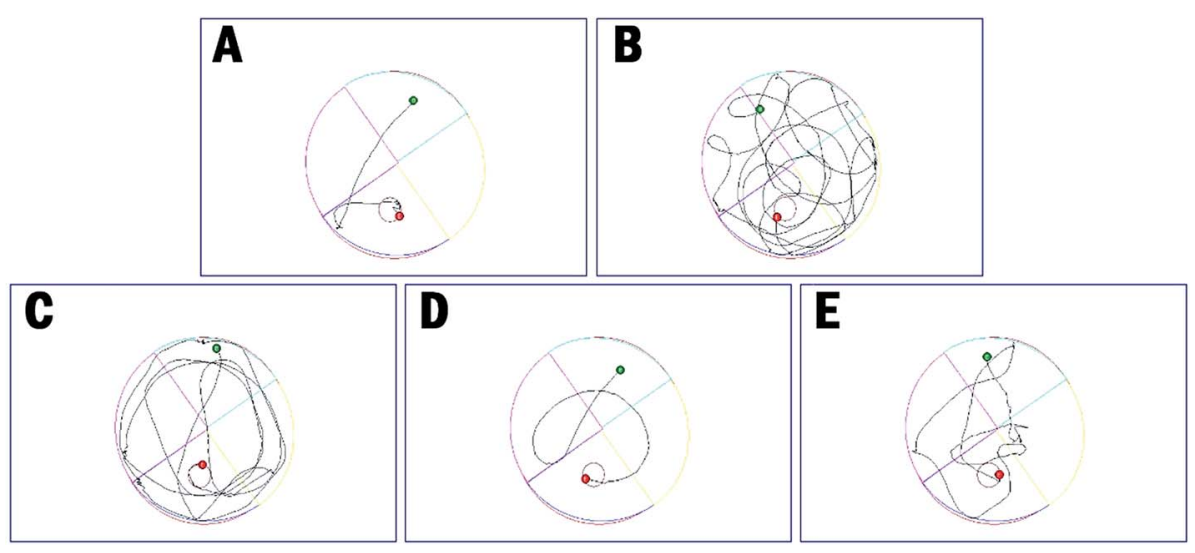

Fig. 6 The trajectories of mice in control (A), model (B), tacrine (C), 35 (D), and 36 (E) group in the Morris water maze test.

(13.2 \pm 7.6 seconds, $\left.{ }^{* * *} p<0.001\right)$, indicating that 36 considerably ameliorated the cognitive impairment of the treated mice and was much better than tacrine. The results also suggested the critical role of the methoxy group of ferulic acid moiety of compound 36. Removal of this group led to the markedly decrease of the in vivo activity as compared to $\mathbf{3 5}$. We confer there may be two reasons for the results: (1) the methoxy group may enhance the ability of $\mathbf{3 6}$ to penetrate the blood-brain barrier (BBB) and target the central nervous system (CNS); (2) the methoxy group may prevent the metabolism at meta-position of the phenyl ring, thus enhance the concentration of the compound to target CNS.
The distance to target (Table 4 and Fig. 6B) and the trajectories of the mice in each group were also analyzed. Compared to the control group, administration of scopolamine remarkably led to the extended distance to target $(1637.3 \pm 517.1 \mathrm{~cm} v \mathrm{~s}$. $292.8 \pm 206.4 \mathrm{~cm}, * * * * p<0.0001)$. Tacrine and 35 reduced the distance to target $(1125.3 \pm 367.1 \mathrm{~cm}, 1274.9 \pm 452.6 \mathrm{~cm}$, respectively). When treated with 36 , the distance to target was significantly shortened $\left(469.5 \pm 278.8,{ }^{* * * *} p<0.0001\right)$. These results were supported by trajectory analysis. As shown in Fig. 6B, the trajectory of the mice in scopolamine model group was very long and disordered, while tacrine and $\mathbf{3 5}$ groups (Fig. 6C and E) showed shortened distances, but still much

Table 5 ALT and AST activity after the administration of 35 and 36 . Tacrine $\left(30 \mathrm{mg} \mathrm{kg}^{-1}\right)$ was used as the reference compound. Values were expressed as the mean \pm SD $(n=6)$

\begin{tabular}{|c|c|c|c|c|c|}
\hline Group & $8 \mathrm{~h}$ & $22 \mathrm{~h}$ & $36 \mathrm{~h}$ & $72 \mathrm{~h}$ & $96 \mathrm{~h}$ \\
\hline \multicolumn{6}{|l|}{$\operatorname{ALT}\left(\mathbf{U ~ L ~}^{-1}\right)$} \\
\hline Control & $31.4 \pm 2.3$ & $32.9 \pm 5.3$ & $30.5 \pm 3.0$ & $28.2 \pm 3.8$ & $29.1 \pm 6.0$ \\
\hline Tacrine & $28.3 \pm 5.4$ & $34.9 \pm 8.6$ & $32.4 \pm 4.8$ & $30.5 \pm 3.4$ & $30.5 \pm 6.0$ \\
\hline 36 & $32.0 \pm 7.7$ & $27.8 \pm 5.0$ & $27.8 \pm 7.5$ & $30.7 \pm 4.0$ & $27.5 \pm 5.7$ \\
\hline \multicolumn{6}{|l|}{$\operatorname{AST}\left(\mathbf{U ~ L ~}^{-\mathbf{1}}\right)$} \\
\hline 35 & $102.6 \pm 14.3$ & $93.7 \pm 12.0$ & $73.0 \pm 10.0$ & $78.1 \pm 10.3$ & $82.1 \pm 16.7$ \\
\hline 36 & $91.2 \pm 19.8$ & $96.7 \pm 15.6$ & $78.0 \pm 14.6$ & $88.9 \pm 24.1$ & $77.9 \pm 16.2$ \\
\hline
\end{tabular}


A

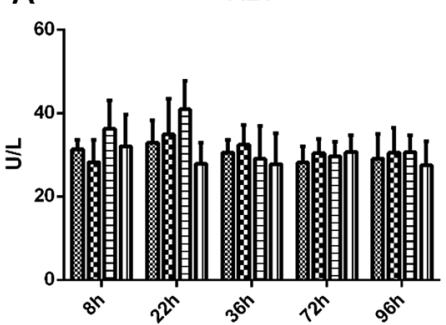

B

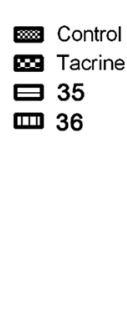

AST

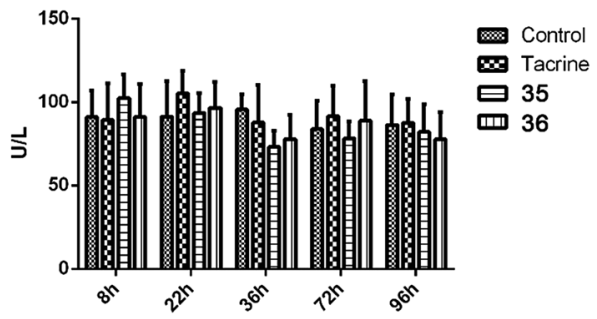

Fig. 7 ALT (A) and AST (B) activity after the administration of tacrine, 35, and 36. Values are expressed as mean \pm SEM ( $n=6 ; t$ test, compared to the control of the same time after administration).

longer than the control group (Fig. 6A). Mice treated with 36 almost recovered to the normal cognition (Fig. 6D), with a similar orientation and distance to that of the normal mice. Taken together, these results supported that $\mathbf{3 6}$ remarkably ameliorated the cognition impairment caused by scopolamine.

\section{Hepatotoxicity studies}

Given that the serious hepatotoxicity of tacrine has been the primary limitation for its clinical use, to ensure the safety of $\mathbf{3 5}$ and 36 for further development, we next investigated the possible drug-induced hepatotoxicity by comparing their toxic profile to tacrine. Heparinized serum was collected $8 \mathrm{~h}, 22 \mathrm{~h}$, $36 \mathrm{~h}, 72 \mathrm{~h}$, and $96 \mathrm{~h}$ after the administration of tacrine, 35 and 36 for the evaluation of the levels of alanine aminotransferase (ALT) and aspartate aminotransferase (AST), two known biomarkers of live damage (Table 5 and Fig. 7). Compared to the control group, after the treatment of tacrine, the levels of ALT and AST were slightly induced at $22 \mathrm{~h}$, but in general, no remarkable damage was observed. As expected, 36 did not showed any hepatotoxicity at all the time points, the level of ALT and AST even slightly reduced at $22 \mathrm{~h}, 36 \mathrm{~h}$, and $96 \mathrm{~h}$ for ALT

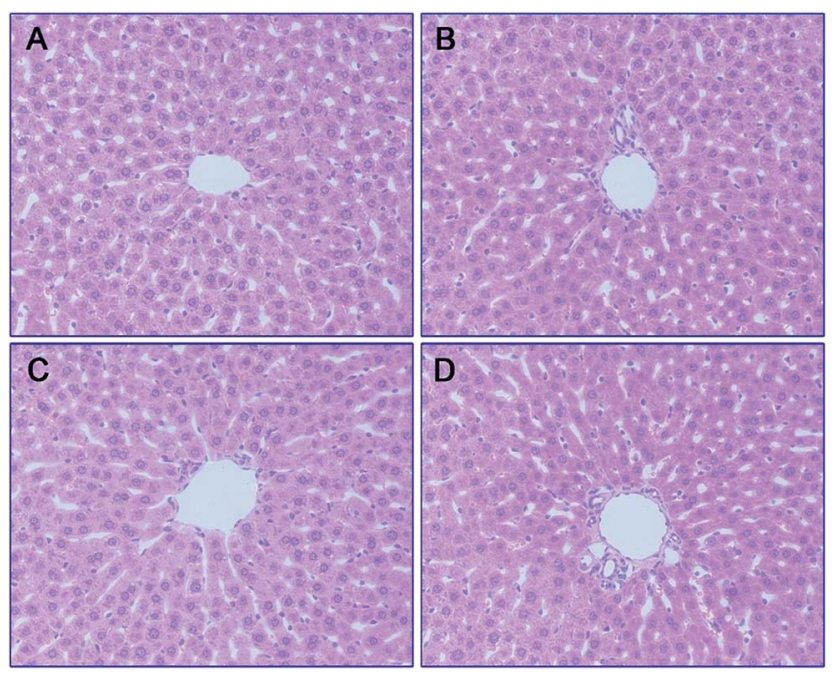

Fig. 8 Histomorphological appearance of livers of male mice after treatment with the solvent only (control, A), or $22 \mathrm{~h}$ after administration of tacrine (B), 35 (C), or 36 (D). HE staining, original magnification $\times 200$. and $36 \mathrm{~h}$ and $96 \mathrm{~h}$ for AST, compared to those of tacrine group. The results indicated the hepatic safety profile of 36 . Interestingly, 35 exhibited an induction of the ALT ( $36.3 \pm 6.9$ vs. $31.4 \pm$ 2.3 at $8 \mathrm{~h}, 40.9 \pm 6.9 v s .32 .9 \pm 5.3$ at $22 \mathrm{~h}$ ) and AST level (102.6 \pm 14.3 vs. $91.1 \pm 16.0$ at $8 \mathrm{~h}$ ) compared to the control group, indicating a potential toxic effect of this compound. When the time extended to $72 \mathrm{~h}$ and $96 \mathrm{~h}$, the levels of ALT and AST were comparable to those of control group. Considering the structural difference between $\mathbf{3 5}$ and $\mathbf{3 6}$, we can speculate that the methoxy group was beneficial to the hepatic safety. The results were also in accordance with those from the behavioral studies. Therefore, it is important to introduce proper groups at this position in order to avoid undesired metabolism.

To further analyze the hepatotoxicity of $\mathbf{3 5}$ and 36, morphologic studies by immunohistochemical staining were applied. Treatment of tacrine (Fig. 8B), 35 (Fig. 8C) or 36 (Fig. 8D) did not result in remarkable morphologic changes in liver compared to the control group (Fig. 8A). Taken together, 36 exhibited the highest safety among all the test compounds, ensuring its further development.

\section{Conclusions}

CY-1 was a tacrine-ferulic acid hybrid reported by our group previously. Guided by this compound, in the present studies, a series of tacrine-cinnamic acid hybrids were designed and synthesized so as to identify the optimal substitution on the phenyl ring of the cinnamic acid moiety. Although there are several publications about tacrine-ferulic acid hybrid, as far as we concerned, this is the first medicinal chemistry study on the ferulic acid moiety. In vitro assays proved that most of the compounds effectively inhibited ChEs in the nanomolar range. Additionally, some interesting information was summarized from the SAR study and can guide the further optimization of this series of compounds. 36 was one of the most potent analogs, which was about 4 -fold more active than the parent compound CY-1 against AChE. Kinetic studies and molecular docking indicated that 36 inhibited $\mathrm{AChE}$ in a mixed-type manner by simultaneously binding to CAS and PAS of AChE. This compound effectively inhibited the self-induced $A \beta_{1-42}$ aggregation, and exhibited cytoprotective effects against $\mathrm{H}_{2} \mathrm{O}_{2}$ induced cell damage. Meanwhile, it was proved to be non-toxic to PC-12 cells when it exerted its biological functions, indicating its good safety. The in vitro assays confirmed the 
multifunctional potent manner of $\mathbf{3 6}$ as potential anti-AD agent. Therefore, it was subjected to in vivo evaluation including Morris water maze test and hepatotoxicity studies. 36 remarkably reduced the scopolamine-induced cognitive impairment in animal model and showed very low hepatotoxicity under the therapeutic concentration. Altogether, 36 can be considered as a promising lead compound for further identification of new anti-AD agents.

\section{Experimental sections}

\section{Chemistry}

General experimental. Melting points were determined on a Mel-TEMP II melting point apparatus and are uncorrected. ${ }^{1} \mathrm{H}$ NMR spectra were recorded with a Bruker Avance $300 \mathrm{MHz}$ spectrometer at $300 \mathrm{~K}$, using TMS as an internal standard. MS spectra were recorded on a Shimadzu GC-MS 2010 (EI) or a Mariner Mass Spectrum (ESI) or a LC/MSD TOF HR-MS Spectrum. All compounds were routinely checked by TLC and ${ }^{1} \mathrm{H}$ NMR. TLCs and preparative thin-layer chromatography were performed on silica gel GF/UV 254 supported by glass plate, and the chromatograms were performed on silica gel (200-300 mesh) visualized under UV light at 254 and $365 \mathrm{~nm}$. Purity for final compounds was greater than $95 \%$ and was measured by HPLC with Agilent Technologies 1260 infinity $\mathrm{C}_{18} 4.60 \mathrm{~mm} \times$ $150 \mathrm{~mm}$ column using a mixture of solvent methanol/water or acetonitrile/water at the flow rate of $0.5 \mathrm{~mL} \mathrm{~min}^{-1}$ and peak detection at $254 \mathrm{~nm}$ under UV. All solvents were reagent grade and, when necessary, were purified and dried by standards methods. Concentration of solutions after reactions and extractions involved the use of a rotary evaporator operating at a reduced pressure of $c a$. 20 Torr. Organic solutions were dried over anhydrous sodium sulfate. Analytical results are within ( $0.40 \%$ of the theoretical values).

$N$-(1,2,3,4-Tetrahydroacridin-9-yl)ethane-1,2-diamine (4). To a solution of 3 (9-chlorotetrahydroacridine) ( $2 \mathrm{~g}, 9.2 \mathrm{mmol}$ ) in 10 $\mathrm{mL}$ of pentanol, diaminoethane $(2.76 \mathrm{~g}, 45.94 \mathrm{mmol})$ were added. After refluxing for $24 \mathrm{~h}$, the solution was cooled to room temperature and then acidified with hydrochloric acid. The solution was extracted with acid water $(4 \times 10 \mathrm{~mL})$. The combined aqueous phase was basified by $\mathrm{NaOH}$ and then extracted with $\mathrm{CH}_{2} \mathrm{Cl}_{2}(4 \times 15 \mathrm{~mL})$. The water phase was combined and washed with brine, dried over anhydrous $\mathrm{Na}_{2} \mathrm{SO}_{4}$ overnight, and evaporated in vacuo. The residue was purified by column chromatography $\left(\mathrm{CH}_{2} \mathrm{Cl}_{2} / \mathrm{MeOH}=20: 1, \mathrm{v} / \mathrm{v}\right.$, with $0.1 \%$ triethylamine). $1.5 \mathrm{~g}$ yellow oil was given (67.6\%). ${ }^{1} \mathrm{H}$ NMR $\left(\mathrm{CD}_{3} \mathrm{OD}\right): \delta$ 8.13-8.10 (m, 1H, ArH), 7.78-7.75 (m, 1H, ArH), 7.60-7.54 (m, 1H, ArH), 7.42-7.36 (m, 1H, ArH), $3.61(\mathrm{t}, J=$ $\left.7.50 \mathrm{~Hz}, 2 \mathrm{H}, \mathrm{NH}-\mathrm{CH}_{2}\right), 2.96-2.91\left(\mathrm{~m}, 4 \mathrm{H}, \mathrm{C} 4-\mathrm{H}_{2}, \mathrm{C}_{2}-\mathrm{NH}_{2}\right)$, 2.76 (br, 2H, C1- $\mathrm{H}_{2}$ ), 1.91-1.88 (m, 4H, C3- $\left.\mathrm{H}_{2}, \mathrm{C} 2-\mathrm{H}_{2}\right)$; MS (GC) m/z (\% rel. Int.) $241\left(\mathbf{M}^{+}, 45\right), 197$ (100) (found C, 74.99; H, 8.18; $\mathrm{N}, 16.98 ; \mathrm{C}_{15} \mathrm{H}_{19} \mathrm{~N}_{3}$ requires $\left.\mathrm{C}, 74.65 ; \mathrm{H}, 7.94 ; \mathrm{N}, 17.41\right)$.

$\mathrm{N}-(2-((1,2,3,4-$ Tetrahydroacridin-9-yl)amino)ethyl)cinnamamide (8). ${ }^{45}$ Cinnamic acid $(0.123 \mathrm{~g}, 0.83 \mathrm{mmol})$, pyBOP $(0.44 \mathrm{~g}, 0.99$ $\mathrm{mmol})$, and DIPEA $(0.14 \mathrm{~g}, 1.08 \mathrm{mmol})$ were dissolved in $3 \mathrm{~mL}$ of $\mathrm{CH}_{2} \mathrm{Cl}_{2}$, and the mixture was stirred at room temperature for $40 \mathrm{~min}$. Then a solution of $4(0.2 \mathrm{~g}, 0.83 \mathrm{mmol})$ in $2 \mathrm{~mL} \mathrm{CH}_{2} \mathrm{Cl}_{2}$ was added. After being stirred for overnight at room temperature. The solvent was removed under vacuo, $20 \mathrm{~mL}$ ethyl acetate was added, the solid was filtered. Then the solid was purified by column chromatography $\left(\mathrm{CH}_{2} \mathrm{Cl}_{2} / \mathrm{MeOH}=50: 1, \mathrm{v} / \mathrm{v}\right.$, with $0.1 \%$ triethylamine) to give a white powder $0.12 \mathrm{~g}$ (39.1\%). Mp 186$187{ }^{\circ} \mathrm{C} .{ }^{1} \mathrm{H}$ NMR $(300 \mathrm{MHz}, \mathrm{DMSO}-d 6): \delta 8.53(\mathrm{t}, J=6.10 \mathrm{~Hz}, 1 \mathrm{H}$, ArH), 8.47 (d, $J=8.64 \mathrm{~Hz}, 1 \mathrm{H}, \mathrm{ArH}), 7.96(\mathrm{~s}, 1 \mathrm{H}, \mathrm{CONH}), 7.86(\mathrm{t}, J$ $=7.58 \mathrm{~Hz}, \mathrm{ArH}), 7.60-7.75(\mathrm{~m}, 3 \mathrm{H}, \mathrm{ArH}$ and $\mathrm{NH}), 7.40(\mathrm{~d}, J=$ $6.84 \mathrm{~Hz}, 3 \mathrm{H}, \mathrm{ArH}$ and $\mathrm{COCH}=\mathrm{CH}), 6.57(\mathrm{~d}, J=15.81 \mathrm{~Hz}, 1 \mathrm{H}$, $\mathrm{COC} \underline{\mathrm{H}}=\mathrm{CH}), 4.02\left(\mathrm{~d}, J=5.40 \mathrm{~Hz}, 2 \mathrm{H}, \mathrm{NHCH}_{2}\right), 3.57(\mathrm{~d}, J=$ $\left.5.40 \mathrm{~Hz}, 2 \mathrm{H}, \mathrm{CH}_{2} \mathrm{NHCO}\right), 2.94$ (br, $2 \mathrm{H}, \mathrm{C} 4-\mathrm{H}_{2}$ ), 2.68 (br, 2H, C1$\mathrm{H}_{2}$ ), 1.82 (br, 4H, C2- $\mathrm{H}_{2}$ and $\left.\mathrm{C} 3-\mathrm{H}_{2}\right) .{ }^{13} \mathrm{C} \mathrm{NMR} \mathrm{(125} \mathrm{MHz,}$ $\left.\mathrm{CDCl}_{3}\right): \delta 167.61,157.94,151.06,146.59,141.52,134.68,129.85$, 128.86, 128.66, 127.86, 127.67, 123.86, 122.85, 120.37, 119.73, $115.85,63.96,49.84,40.68,33.43,25.01,22.95,22.53$. HRMS (ESI): calcd for $\mathrm{C}_{24} \mathrm{H}_{25} \mathrm{~N}_{3} \mathrm{O}[\mathrm{M}+\mathrm{H}]^{+}$372.207, found 372.2074. HPLC $\left(70 \%\right.$ methanol in water with $\left.0.5 \% \mathrm{H}_{3} \mathrm{PO}_{4}\right): t_{\mathrm{R}}=3.56 \mathrm{~min}$, $97.077 \%$.

(E)-N-(2-((1,2,3,4-Tetrahydroacridin-9-yl)amino)ethyl)-3-(o-tolyl)acrylamide (9). According to the procedure used to synthesize 8, 9 was synthesized from (E)-3-(o-tolyl)acrylic acid $(0.14 \mathrm{~g}, 0.83$ $\mathrm{mmol})$ to give a white powder $0.14 \mathrm{~g}(43.89 \%)$. Mp 202-204 ${ }^{\circ} \mathrm{C}$. ${ }^{1} \mathrm{H}$ NMR (300 MHz, DMSO-d6): $\delta 8.83$ (s, 1H, ArH), 8.53 (d, $J=$ $8.53 \mathrm{~Hz}, 1 \mathrm{H}, \mathrm{ArH}), 8.00$ (d, $J=8.19 \mathrm{~Hz}, 2 \mathrm{H}, \mathrm{ArH}$ and CONH), 7.84 $(\mathrm{t}, J=7.59 \mathrm{~Hz}, 1 \mathrm{H}, \mathrm{ArH}), 7.65(\mathrm{~d}, J=15.72 \mathrm{~Hz}, 1 \mathrm{H}, \mathrm{COCH}=\mathrm{C} \underline{\mathrm{H}})$, $7.56(\mathrm{t}, J=7.68 \mathrm{~Hz}, 1 \mathrm{H}, \operatorname{ArH}), 7.45$ (d, $J=6.93 \mathrm{~Hz}, 1 \mathrm{H}, \mathrm{ArH}), 7.24$ (br, 2H, ArH and NH), $6.53(\mathrm{~d}, J=15.66 \mathrm{~Hz}, \mathrm{COCH}=\mathrm{CH}), 4.02(\mathrm{~d}$, $J=6.18 \mathrm{~Hz}, 2 \mathrm{H}, \mathrm{NHC} \mathrm{H}_{2}$ ), 3.56 (d, $\left.J=5.22 \mathrm{~Hz}, 2 \mathrm{H}, \mathrm{C} \mathrm{H}_{2} \mathrm{NHCO}\right)$, $3.00\left(\mathrm{~s}, 3 \mathrm{H}, \mathrm{CH}_{3}\right) 2.71\left(\mathrm{~s}, 2 \mathrm{H}, \mathrm{C} 4-\mathrm{H}_{2}\right), 2.35\left(\mathrm{~s}, 2 \mathrm{H}, \mathrm{C} 1-\underline{\mathrm{H}_{2}}\right), 1.82(\mathrm{~s}$, $\left.4 \mathrm{H}, \mathrm{C} 2-\underline{\mathrm{H}_{2}}, \mathrm{C} 3-\underline{\mathrm{H}_{2}}\right) .{ }^{13} \mathrm{C}$ NMR $(125 \mathrm{MHz}, \mathrm{DMSO}-d \overline{6)} \delta$ 166.78, $156.12,148.29,137.22,137.00,134.12,132.79,131.15,129.76$, $126.87,126.45,125.50,123.47,119.56,115.95,111.91,48.70$, 28.44, 24.31, 21.98, 21.44, 20.81. HRMS (ESI): calcd for $\mathrm{C}_{25} \mathrm{H}_{27} \mathrm{~N}_{3} \mathrm{O}[\mathrm{M}+\mathrm{H}]^{+} 386.2227$, found 386.2226. HPLC $(70 \%$ methanol in water with $\left.0.5 \% \mathrm{H}_{3} \mathrm{PO}_{4}\right): t_{\mathrm{R}}=4.53 \mathrm{~min}, 95.828 \%$.

(E)-N-(2-((1,2,3,4-Tetrahydroacridin-9-yl)amino)ethyl)-3-(m-tolyl)acrylamide (10). According to the procedure used to synthesize $\mathbf{8}$, 10 was synthesized from $(E)-3-(m$-tolyl)acrylic acid $(0.14 \mathrm{~g}, 0.83$ $\mathrm{mmol})$ to give a white powder $0.14 \mathrm{~g}(43.89 \%)$. Mp $200-202{ }^{\circ} \mathrm{C} .{ }^{1} \mathrm{H}$ NMR (300 MHz, DMSO-d6): $\delta$ 8.51-8.46 (m, 2H, ArH), 7.97 (br, $1 \mathrm{H}, \mathrm{CONH}), 7.87$ (t, $J=7.56 \mathrm{~Hz}, 1 \mathrm{H}, \mathrm{ArH}), 7.78(\mathrm{~d}, J=7.65 \mathrm{~Hz}, 1 \mathrm{H}$, ArH), 7.58 (t, $J=7.49 \mathrm{~Hz}, 1 \mathrm{H}, \operatorname{ArH}), 7.40$ (d, $J=15.84 \mathrm{~Hz}, 1 \mathrm{H}$, $\mathrm{COCH}=\mathrm{CH}), 7.35-7.26(\mathrm{~m}, 3 \mathrm{H}, \mathrm{ArH}$ and $\mathrm{NH}), 7.19(\mathrm{~d}, J=$ $7.26 \mathrm{~Hz}, 1 \mathrm{H}, \mathrm{ArH}) 6.56(\mathrm{~d}, J=15.81 \mathrm{~Hz}, 1 \mathrm{H}, \mathrm{COCH}=\mathrm{CH}), 4.02(\mathrm{~d}$, $J=5.46,2 \mathrm{H}, \mathrm{NHCH}_{2}$ ), 3.57 (d, $\left.J=5.61 \mathrm{~Hz}, 2 \mathrm{H}, \mathrm{C} \mathrm{H}_{2} \mathrm{NHCO}\right)$, 2.95 (br, 2H, C4- $\left.\mathrm{H}_{2}\right), 2.68\left(\mathrm{br}, 2 \mathrm{H}, \mathrm{C} 1-\mathrm{H}_{2}\right), 2.31\left(\mathrm{~s}, 3 \mathrm{H}, \mathrm{CH}_{3}\right), 1.83$ (br, 4H, C2- $-\mathrm{H}_{2}$ and $\left.\mathrm{C} 3-\mathrm{H}_{2}\right) .{ }^{13} \mathrm{C}$ NMR (125 MHz, DMSO-d6): $\delta 167.06,156.66,151.00,139.99,138.64,138.33,135.08,133.31$, $130.86,129.35,128.61,125.79,125.60,125.26,121.68,119.54$, 116.00, 111.92, 48.82, 28.42, 24.21, 21.92, 21.38, 20.79. HRMS (ESI): calcd for $\mathrm{C}_{25} \mathrm{H}_{27} \mathrm{~N}_{3} \mathrm{O}[\mathrm{M}+\mathrm{H}]^{+}$386.2227, found 386.2215. HPLC (70\% methanol in water with $\left.0.5 \% \mathrm{H}_{3} \mathrm{PO}_{4}\right): t_{\mathrm{R}}=4.97 \mathrm{~min}$, $99.188 \%$.

(E)-N-(2-((1,2,3,4-Tetrahydroacridin-9-yl)amino)ethyl)-3-(p-tolyl)acrylamide (11). According to the procedure used to synthesize $\mathbf{8}$, 11 was synthesized from (E)-3-(p-tolyl)acrylic acid ( $0.14 \mathrm{~g}, 0.83$ $\mathrm{mmol})$ to give a white powder $0.17 \mathrm{~g}(53.29 \%)$. Mp $212-214{ }^{\circ} \mathrm{C}$. 
${ }^{1} \mathrm{H}$ NMR (300 MHz, DMSO- $\left.d 6\right): \delta 8.47$ (d, $J=7.41 \mathrm{~Hz}, 2 \mathrm{H}, \mathrm{ArH}$ ), 7.95 (br, 1H, CONH), 7.86 (t, $J=7.32 \mathrm{~Hz}, 1 \mathrm{H}, \mathrm{ArH}), 7.78(\mathrm{~d}, J=$ $7.37 \mathrm{~Hz}, 1 \mathrm{H}, \mathrm{ArH}), 7.57$ (t, $J=7.56 \mathrm{~Hz}, 1 \mathrm{H}, \mathrm{ArH}), 7.45-7.42(\mathrm{~m}, 3 \mathrm{H}$ $\mathrm{ArH}$ and $\mathrm{NH}$ and $\mathrm{COCH}=\mathrm{CH}), 7.22(\mathrm{~d}, J=7.08 \mathrm{~Hz}, 1 \mathrm{H}, \operatorname{ArH})$, $6.81(\mathrm{~d}, J=15.69 \mathrm{~Hz}, 1 \mathrm{H}, \mathrm{COC} \underline{\mathrm{H}}=\mathrm{CH}), 4.02\left(\mathrm{br}, 2 \mathrm{H}, \mathrm{NHC}_{2}\right.$ ), 3.57 (br, 2H, C $\mathrm{H}_{2} \mathrm{NHCO}$ ), 2.94 (br, 2H, C4- $\mathrm{H}_{2}$ ), 2.68 (br, $2 \mathrm{H}$, $\left.\mathrm{C} 1-\mathrm{H}_{2}\right), 2.31\left(\mathrm{~s}, 3 \mathrm{H}, \mathrm{CH}_{3}\right), 1.83\left(\mathrm{br}, 4 \mathrm{H}, \mathrm{C} 2-\underline{\mathrm{H}_{2}}\right.$ and $\left.\mathrm{C} 3-\mathrm{H}_{2}\right) .{ }^{13} \mathrm{C}$ NMR (125 MHz, DMSO-d6): $\delta$ 167.19, 156.69, 150.99, 139.98, 139.88, 138.32, 133.32, 132.38, 130.06, 128.07, 125.80, 125.60, 120.78, 119.52, 116.00, 111.91, 48.88, 28.41, 24.21, 21.92, 21.43, 20.79. HRMS (ESI): calcd for $\mathrm{C}_{25} \mathrm{H}_{27} \mathrm{~N}_{3} \mathrm{O}[\mathrm{M}+\mathrm{H}]^{+} 386.2227$, found 386.2219 . HPLC $(70 \%$ methanol in water with $0.5 \%$ $\left.\mathrm{H}_{3} \mathrm{PO}_{4}\right): t_{\mathrm{R}}=4.75 \min , 98.085 \%$.

(E)-3-(2-Methoxyphenyl)-N-(2-((1,2,3,4-tetrahydroacridin-9-yl)amino)ethyl)acrylamide (12). According to the procedure used to synthesize 8, 12 was synthesized from (E)-3-(2-methoxyphenyl) acrylic acid $(0.15 \mathrm{~g}, 0.83 \mathrm{mmol})$ to give a white powder $0.15 \mathrm{~g}$ (45.05\%). Mp 173-175 ${ }^{\circ} \mathrm{C} .{ }^{1} \mathrm{H}$ NMR (300 MHz, DMSO- $\left.d 6\right): \delta 8.48-$ $8.45(\mathrm{~m}, 2 \mathrm{H}, \mathrm{ArH}), 7.85(\mathrm{t}, J=7.02 \mathrm{~Hz}, 2 \mathrm{H}, \mathrm{ArH}$ and CONH$), 7.78$ $(\mathrm{d}, J=7.77 \mathrm{~Hz}, 1 \mathrm{H}, \mathrm{ArH}), 7.66(\mathrm{~d}, J=15.96 \mathrm{~Hz}, 1 \mathrm{H}, \mathrm{COCH}=\mathrm{C} \underline{\mathrm{H}})$, $7.57(\mathrm{t}, J=6.93 \mathrm{~Hz}, 1 \mathrm{H}, \operatorname{ArH}), 7.49(\mathrm{~d}, J=7.23,1 \mathrm{H}, \operatorname{ArH}), 7.36(\mathrm{t}, J$ $=7.62 \mathrm{~Hz}, 1 \mathrm{H}, \operatorname{ArH}), 7.07(\mathrm{~d}, J=8.25 \mathrm{~Hz}, 1 \mathrm{H}, \operatorname{ArH}), 6.97(\mathrm{t}, J=$ $7.35 \mathrm{~Hz}, \mathrm{ArH}), 6.60$ (d, $J=15.96 \mathrm{~Hz}, 1 \mathrm{H}, \mathrm{COC} \underline{\mathrm{H}}=\mathrm{CH}), 4.00(\mathrm{~d}, J$ $\left.=5.56 \mathrm{~Hz}, 2 \mathrm{H}, \mathrm{NHC}_{2}\right), 3.85\left(\mathrm{~s}, 3 \mathrm{H}, \mathrm{OCH}_{3}\right), 3.55(\mathrm{~d}, J=5.71 \mathrm{~Hz}$, $2 \mathrm{H}, \mathrm{C} \mathrm{H}_{2} \mathrm{NHCO}$ ), 2.94 (br, 2H, C4- $\mathrm{H}_{2}$ ), 2.68 (br, 2H, C1- $\mathrm{H}_{2}$ ), 1.83 (br, $4 \mathrm{H}, \mathrm{C} 2-\mathrm{H}_{2}$ and $\left.\mathrm{C} 3-\mathrm{H}_{2}\right) .{ }^{13} \mathrm{C}$ NMR $(125 \mathrm{MHz}, \mathrm{DMSO}-$ $d 6): \delta 167.40,158.11,156.48,151.24,138.65,135.01,133.12$, $131.55,128.50,125.63,123.51,122.25,121.22,119.85,116.16$, 111.15, 56.06, 48.86, 46.35, 28.61, 26.39, 24.24, 21.96, 20.85. HRMS (ESI): calcd for $\mathrm{C}_{25} \mathrm{H}_{27} \mathrm{~N}_{3} \mathrm{O}_{2}[\mathrm{M}+\mathrm{H}]^{+} 402.2176$, found 402.2169. HPLC (70\% methanol in water with $\left.0.5 \% \mathrm{H}_{3} \mathrm{PO}_{4}\right): t_{\mathrm{R}}=$ $3.63 \mathrm{~min}, 97.648 \%$.

(E)-3-(3-Methoxyphenyl)-N-(2-((1,2,3,4-tetrahydroacridin-9-yl)amino)ethyl)acrylamide (13). According to the procedure used to synthesize 8, 13 was synthesized from (E)-3-(3-methoxyphenyl) acrylic acid $(0.15 \mathrm{~g}, 0.83 \mathrm{mmol})$ to give a white powder $0.11 \mathrm{~g}$ (33.03\%). Mp 169-172 ${ }^{\circ} \mathrm{C} .{ }^{1} \mathrm{H}$ NMR (300 MHz, DMSO- $\left.d 6\right): \delta 8.49-$ $8.46(\mathrm{~m}, 2 \mathrm{H}, \mathrm{ArH}), 7.96$ (br, $1 \mathrm{H}, \mathrm{CONH}), 7.87(\mathrm{t}, J=6.87 \mathrm{~Hz}, 1 \mathrm{H}$, $\operatorname{ArH}), 7.78$ (d, $J=7.50 \mathrm{~Hz}, 1 \mathrm{H}, \operatorname{ArH}), 7.57$ (t, $J=7.08 \mathrm{~Hz}, 1 \mathrm{H}$, $\mathrm{ArH}), 7.40(\mathrm{~d}, J=15.81 \mathrm{~Hz}, 1 \mathrm{H}, \mathrm{COCH}=\mathrm{CH}), 7.32(\mathrm{t}, J=7.95 \mathrm{~Hz}$, 1H, ArH), 7.13-7.10 (m, 2H, ArH and NH), $6.95\left(\mathrm{dd}, J_{1}=7.95 \mathrm{~Hz}\right.$, $\left.J_{2}=2.04 \mathrm{~Hz}, 1 \mathrm{H}, \mathrm{ArH}\right), 6.57(\mathrm{~d}, J=15.81 \mathrm{~Hz}, 1 \mathrm{H}, \mathrm{COCH}=\mathrm{CH})$, $4.02\left(\mathrm{~d}, J=5.65 \mathrm{~Hz}, 2 \mathrm{H}, \mathrm{NHC} \mathrm{H}_{2}\right), 3.77\left(\mathrm{~s}, 3 \mathrm{H}, \mathrm{OCH}_{3}\right), 3.57$ (d, $J$ $\left.=5.55 \mathrm{~Hz}, 2 \mathrm{H}, \mathrm{C} \mathrm{H}_{2} \mathrm{NHCO}\right), 2.95\left(\mathrm{br}, 2 \mathrm{H}, \mathrm{C} 4-\mathrm{H}_{2}\right), 2.68(\mathrm{br}, 2 \mathrm{H}$, $\left.\mathrm{C} 1-\mathrm{H}_{2}\right), 1.83\left(\mathrm{br}, \overline{4 \mathrm{H}}, \mathrm{C} 2-\mathrm{H}_{2}\right.$ and $\left.\mathrm{C} 3-\mathrm{H}_{2}\right) .{ }^{13} \mathrm{C} \mathrm{NMR}(125 \mathrm{MHz}$, $\left.\mathrm{CDCl}_{3}\right): \delta 167.64,159.86,157.81,151.14,146.49,141.27,136.12$, 129.83 , 128.67, 127.50, 123.83, 122.92, 120.84, 120.39, 119.67, 115.72, 115.40, 113.16, 55.26, 49.87, 40.67, 33.37, 25.00, 22.93, 22.50. HRMS (ESI): calcd for $\mathrm{C}_{25} \mathrm{H}_{27} \mathrm{~N}_{3} \mathrm{O}_{2}[\mathrm{M}+\mathrm{H}]^{+} 402.2176$, found 402.2174. HPLC (70\% methanol in water with $0.5 \%$ $\left.\mathrm{H}_{3} \mathrm{PO}_{4}\right): t_{\mathrm{R}}=3.68 \min , 98.401 \%$.

(E)-3-(4-Methoxyphenyl)-N-(2-((1,2,3,4-tetrahydroacridin-9-yl)amino)ethyl)acrylamide (14). According to the procedure used to synthesize 8, 14 was synthesized from (E)-3-(4-methoxyphenyl) acrylic acid $(0.15 \mathrm{~g}, 0.83 \mathrm{mmol})$ to give a white powder $0.16 \mathrm{~g}$ (48.05\%). Mp 180-182 ${ }^{\circ} \mathrm{C} .{ }^{1} \mathrm{H}$ NMR (300 MHz, DMSO-d6): $\delta{ }^{1} \mathrm{H}$ NMR (300 MHz, DMSO-d6): $\delta$ 8.47-8.44 (m, 2H, ArH), 7.93 (br,
1H, CONH), 7.72 (t, $J=7.01 \mathrm{~Hz}, 1 \mathrm{H}, \operatorname{ArH}), 7.52(\mathrm{~d}, J=7.97 \mathrm{~Hz}$, $2 \mathrm{H}, \mathrm{ArH}), 7.46(\mathrm{~d}, J=15.93 \mathrm{~Hz}, 1 \mathrm{H}, \mathrm{COCH}=\mathrm{CH}), 7.16-7.12(\mathrm{~m}$, 2H, ArH and NH), 6.99 (d, $J=7.98 \mathrm{~Hz}, 2 \mathrm{H}, \mathrm{ArH}), 6.50$ (d, $J=$ $15.94 \mathrm{~Hz}, 1 \mathrm{H}, \mathrm{COC} \underline{\mathrm{H}}=\mathrm{CH}), 4.05\left(\mathrm{~d}, J=5.75 \mathrm{~Hz}, 2 \mathrm{H}, \mathrm{NHC}_{2}\right)$, $3.83\left(\mathrm{~s}, 3 \mathrm{H}, \mathrm{OCH}_{3}\right), 3.50$ (d, $\left.J=5.74 \mathrm{~Hz}, 2 \mathrm{H}, \mathrm{C} \mathrm{H}_{2} \mathrm{NHCO}\right), 2.89$ (br, 2H, C4 $-\underline{\mathrm{H}_{2}}$ ), 2.72 (br, 2H, C1- $\mathrm{H}_{2}$ ), 1.86 (br, $4 \mathrm{H}, \mathrm{C} 2-\underline{\mathrm{H}_{2}}$ and C3 $\left.-\mathrm{H}_{2}\right) .{ }^{13} \mathrm{C}$ NMR (125 MHz, DMSO-d6): $\delta$ 167.40, 158.11, $156.46,151.26,138.67,135.01,133.11,131.55,128.50,125.62$, $123.51,122.24,121.22,119.87,116.17,112.16,56.06,48.86$, 46.35, 28.62, 26.39, 24.24, 21.96, 20.86. HRMS (ESI): calcd for $\mathrm{C}_{25} \mathrm{H}_{27} \mathrm{~N}_{3} \mathrm{O}_{2}[\mathrm{M}+\mathrm{H}]^{+}$402.2176, found 402.2182. HPLC (70\% methanol in water with $\left.0.5 \% \mathrm{H}_{3} \mathrm{PO}_{4}\right): t_{\mathrm{R}}=5.44 \mathrm{~min}, 96.122 \%$.

(E)-3-(2,3-Dimethoxyphenyl)-N-(2-((1,2,3,4-tetrahydroacridin-9-yl)amino)ethyl)acrylamide (15). According to the procedure used to synthesize 8, 15 was synthesized from (E)-3-(2,3-dimethoxyphenyl) acrylic acid $(0.17 \mathrm{~g}, 0.83 \mathrm{mmol})$ to give a white powder $0.2 \mathrm{~g}$ (55.87\%). Mp 195-197 ${ }^{\circ} \mathrm{C} .{ }^{1} \mathrm{H}$ NMR (300 MHz, DMSO- $\left.d 6\right): \delta 8.53-$ $8.46(\mathrm{~m}, 2 \mathrm{H}, \mathrm{ArH}), 7.94(\mathrm{br}, 1 \mathrm{H}, \mathrm{CONH}), 7.86(\mathrm{t}, J=7.02 \mathrm{~Hz}, 1 \mathrm{H}$, $\mathrm{ArH}), 7.78(\mathrm{~d}, J=7.71 \mathrm{~Hz}, 1 \mathrm{H}, \mathrm{ArH}), 7.65-7.55(\mathrm{~m}, 2 \mathrm{H}, \mathrm{COCH}=\mathrm{CH}$ and $\mathrm{ArH}), 7.11-7.07$ (m, 3H, NH and $\mathrm{ArH}), 6.59$ (d, $J=15.96 \mathrm{~Hz}$, $1 \mathrm{H}, \mathrm{COCH}=\mathrm{CH}), 4.05-3.98\left(\mathrm{~m}, 2 \mathrm{H}, \mathrm{NHC}_{2}\right), 3.81\left(\mathrm{~s}, 3 \mathrm{H}, \mathrm{OCH}_{3}\right)$, $3.73\left(\mathrm{~s}, 3 \mathrm{H}, \mathrm{OCH}_{3}\right), 3.56\left(\mathrm{~d}, J=5.37 \mathrm{~Hz}, 2 \mathrm{H}, \mathrm{C} \mathrm{H}_{2} \mathrm{NHCO}\right), 2.87$ (br, $2 \mathrm{H}, \mathrm{C} 4-\mathrm{H}_{2}$ ), 2.68 (br, $\left.2 \mathrm{H}, \mathrm{C} 1-\mathrm{H}_{2}\right), 1.83$ (br, $4 \mathrm{H}, \mathrm{C} 2-\mathrm{H}_{2}$ and C3$\left.\mathrm{H}_{2}\right) .{ }^{13} \mathrm{C} \mathrm{NMR}$ (125 MHz, DMSO-d6): $\delta$ 167.10, 156.69, 153.32, $147.97,138.34,134.39$, 133.30, 128.70, 125.79, 125.61, 124.89, 123.09, 119.34, 116.03, 114.51, 111.96, 61.12, 60.23, 56.27, 48.73, 46.36, 28.43, 26.42, 24.23, 21.92, 21.01. HRMS (ESI): calcd for $\mathrm{C}_{26} \mathrm{H}_{29} \mathrm{~N}_{3} \mathrm{O}_{3}[\mathrm{M}+\mathrm{H}]^{+}$432.2282, found 432.2278. HPLC (70\% methanol in water with $\left.0.5 \% \mathrm{H}_{3} \mathrm{PO}_{4}\right): t_{\mathrm{R}}=3.21 \mathrm{~min}, 98.413 \%$.

(E)-3-(2,5-Dimethoxyphenyl)-N-(2-((1,2,3,4-tetrahydroacridin-9$y$ l)-amino)ethyl)acrylamide (16). According to the procedure used to synthesize 8, 16 was synthesized from (E)-3-(2,5-dimethoxyphenyl)acrylic acid $(0.17 \mathrm{~g}, 0.83 \mathrm{mmol})$ to give a white powder $0.14 \mathrm{~g}$ (39.11\%). Mp 190-191 ${ }^{\circ} \mathrm{C} .{ }^{1} \mathrm{H}$ NMR $(300 \mathrm{MHz}$, DMSO- $d 6): \delta 8.48-8.46(\mathrm{~m}, 2 \mathrm{H}, \mathrm{ArH}), 7.95$ (br, $1 \mathrm{H}, \mathrm{CONH}), 7.86$ (t, $J=7.501 \mathrm{H}, \mathrm{ArH}), 7.78$ (d, $J=8.13 \mathrm{~Hz}, 1 \mathrm{H}, \mathrm{ArH}), 7.65-7.55$ $(\mathrm{m}, 2 \mathrm{H}, \mathrm{COCH}=\mathrm{CH}$ and $\mathrm{ArH}), 7.04-6.93(\mathrm{~m}, 3 \mathrm{H}, \mathrm{NH}$ and $\mathrm{ArH})$, $6.61(\mathrm{~d}, J=15.87 \mathrm{~Hz}, 1 \mathrm{H}, \mathrm{COC} \underline{\mathrm{H}}=\mathrm{CH}), 4.01(\mathrm{~d}, J=4.92 \mathrm{~Hz}, 2 \mathrm{H}$, $\left.\mathrm{NHC} \underline{\mathrm{H}}_{2}\right), 3.79\left(\mathrm{~s}, 3 \mathrm{H}, \mathrm{OCH}_{3}\right), 3.72\left(\mathrm{~s}, 3 \mathrm{H}, \mathrm{OCH}_{3}\right), 3.56(\mathrm{~d}, J=$ $\left.5.22 \overline{\mathrm{Hz}}, 2 \mathrm{H}, \mathrm{C} \mathrm{H}_{2} \mathrm{NHCO}\right), 2.94$ (br, 2H, C4 $-\underline{\mathrm{H}_{2}}$ ), 2.68 (br, $2 \mathrm{H}$, $\left.\mathrm{C} 1-\underline{\mathrm{H}_{2}}\right), 1.83\left(\overline{\mathrm{br},} 4 \mathrm{H}, \mathrm{C} 2-\underline{\mathrm{H}_{2}}\right.$ and $\left.\mathrm{C} 3-\underline{\mathrm{H}_{2}}\right) .{ }^{13} \overline{\mathrm{C} \mathrm{NMR}}(125 \mathrm{MHz}$, DMSO- $d 6): \delta 167.09,156.69,153.32,147.96,138.34,134.39$, 133.31, 128.70, 125.79, 125.61, 124.89, 123.09, 119.54, 119.14, 116.03, 114.51, 111.96, 61.12, 60.23, 56.27, 48.73, 46.36, 28.43, $26.42,24.23,21.92,21.22,20.80$. HRMS (ESI): calcd for $\mathrm{C}_{26} \mathrm{H}_{29} \mathrm{~N}_{3} \mathrm{O}_{3}[\mathrm{M}+\mathrm{H}]^{+}$432.2282, found 432.2277. HPLC (70\% methanol in water with $\left.0.5 \% \mathrm{H}_{3} \mathrm{PO}_{4}\right): t_{\mathrm{R}}=3.63 \mathrm{~min}, 97.736 \%$.

(E)-N-(2-((1,2,3,4-Tetrahydroacridin-9-yl)amino)ethyl)-3-(2,3,4trimethoxyphenyl)acrylamide (17). According to the procedure used to synthesize 8, 17 was synthesized from (E)-3-(2,3,4-trimethoxyphenyl)acrylic acid $(0.20 \mathrm{~g}, 0.83 \mathrm{mmol})$ to give a white powder $0.13 \mathrm{~g}$ (33.94\%). Mp 206-208 ${ }^{\circ} \mathrm{C} .{ }^{1} \mathrm{H}$ NMR $(300 \mathrm{MHz}$, DMSO- $d 6): \delta 8.50-8.47$ (m, 2H, ArH), 8.00 (br, $1 \mathrm{H}, \mathrm{CONH}), 7.88$ $(\mathrm{t}, J=7.46 \mathrm{~Hz}, 1 \mathrm{H}, \mathrm{ArH}), 7.79(\mathrm{~d}, J=8.07 \mathrm{~Hz}, 1 \mathrm{H}, \mathrm{ArH}), 7.62-7.51$ $(\mathrm{m}, 2 \mathrm{H}, \mathrm{ArH}$ and $\mathrm{COCH}=\mathrm{C} \underline{\mathrm{H}}), 7.28(\mathrm{~d}, J=8.82 \mathrm{~Hz}, 1 \mathrm{H}, \operatorname{ArH})$, $6.88(\mathrm{~d}, J=8.88 \mathrm{~Hz}, 1 \mathrm{H}, \mathrm{ArH}), 6.53(\mathrm{~d}, J=15.84 \mathrm{~Hz}, 1 \mathrm{H}, \mathrm{COC} \underline{\mathrm{H}}=$ $\mathrm{CH}), 4.03\left(\mathrm{~d}, J=5.25 \mathrm{~Hz}, 2 \mathrm{H}, \mathrm{NHC}_{2}\right.$ ), $3.83\left(\mathrm{~s}, 3 \mathrm{H}, \mathrm{OCH}_{3}\right), 3.80$ 
$\left(\mathrm{s}, 3 \mathrm{H}, \mathrm{OCH}_{3}\right), 3.76\left(\mathrm{~s}, 3 \mathrm{H}, \mathrm{OCH}_{3}\right), 3.57(\mathrm{~d}, J=5.82 \mathrm{~Hz}, 2 \mathrm{H}$, $\mathrm{C} \mathrm{H}_{2} \mathrm{NHCO}$ ), 2.96 (br, 2H, C4- $\mathrm{H}_{2}$ ), 2.69 (br, 2H, C1- $\underline{\mathrm{H}_{2}}$ ), 1.84 (br, $4 \mathrm{H}, \mathrm{C} 2-\mathrm{H}_{2}$ and $\left.\mathrm{C} 3-\mathrm{H}_{2}\right) .{ }^{13} \mathrm{C}$ NMR (125 MHz, DMSO-d6): $\delta 167.77,158.45,155.06,152.73,150.63,147.46,142.40,134.25$, $128.81,128.31,123.73,123.48,123.04,121.74,121.29,120.56$, 116.32, 108.89, 61.61, 60.87, 56.37, 48.79, 46.18, 34.05, 25.46, 23.25, 22.91. HRMS (ESI): calcd for $\mathrm{C}_{27} \mathrm{H}_{31} \mathrm{~N}_{3} \mathrm{O}_{4}[\mathrm{M}+\mathrm{H}]^{+}$ 462.2387, found 462.2386. HPLC (80\% methanol in water with $\left.0.5 \% \mathrm{H}_{3} \mathrm{PO}_{4}\right): t_{\mathrm{R}}=3.39 \mathrm{~min}, 96.333 \%$.

(E)-N-(2-((1,2,3,4-Tetrahydroacridin-9-yl)amino)ethyl)-3-(3,4,5trimethoxyphenyl)acrylamide (18). According to the procedure used to synthesize 8, 18 was synthesized from (E)-3-(3,4,5-trimethoxyphenyl)acrylic acid $(0.20 \mathrm{~g}, 0.83 \mathrm{mmol})$ to give a white powder $0.17 \mathrm{~g}$ (44.39\%). Mp 201-202 ${ }^{\circ} \mathrm{C} .{ }^{1} \mathrm{H}$ NMR $(300 \mathrm{MHz}$, DMSO- $d 6): \delta 8.49-8.46(\mathrm{~m}, 2 \mathrm{H}, \mathrm{ArH}), 7.96-7.77(\mathrm{~m}, 3 \mathrm{H}, \mathrm{CONH}$ and $\mathrm{ArH}), 7.60-7.50(\mathrm{~m}, 2 \mathrm{H}, \mathrm{COCH}=\mathrm{CH}$ and $\mathrm{ArH}), 7.27(\mathrm{~d}, J=$ $8.67 \mathrm{~Hz}, 1 \mathrm{H}, \mathrm{ArH}), 6.86(\mathrm{~d}, J=8.79 \mathrm{~Hz}, 1 \mathrm{H}, \mathrm{NH}) 6.51$ (d, $J=$ $15.75 \mathrm{~Hz}, 1 \mathrm{H}, \mathrm{COC} \underline{\mathrm{H}}=\mathrm{CH}), 4.02\left(\mathrm{br}, 2 \mathrm{H}, \mathrm{NHC}_{2}\right), 3.82-3.54$ (m, 11H, $3 * \mathrm{OCH}_{3}$ and $\mathrm{C}_{2} \mathrm{NHCO}$ ), 2.94 (br, $2 \mathrm{H}, \mathrm{C} 4-\mathrm{H}_{2}$ ), 2.68 (br, 2H, C1- $\mathrm{H}_{2}$ ), 1.83 (br, $\overline{4 \mathrm{H}}, \mathrm{C} 2-\mathrm{H}_{2}$ and C3- $\left.\mathrm{H}_{2}\right) .{ }^{13} \mathrm{C}$ NMR (125 MHz, DMSO-d6): $\delta$ 166.43, 158.46, 153.57, 150.65, 150.63, $147.47,139.61,139.24,130.97,128.81,128.32$, 123.74, 123.48, 121.75, 120.55, 116.31, 105.48, 60.55, 56.34, 48.76, 34.05, 25.48, 23.25, 22.92. HRMS (ESI): calcd for $\mathrm{C}_{27} \mathrm{H}_{31} \mathrm{~N}_{3} \mathrm{O}_{4}[\mathrm{M}+\mathrm{H}]^{+}$ 462.2387, found 462.2388. HPLC (70\% methanol in water with $\left.0.5 \% \mathrm{H}_{3} \mathrm{PO}_{4}\right): t_{\mathrm{R}}=2.96 \mathrm{~min}, 98.112 \%$.

(E)-3-(Benzo[d][1,3]dioxol-5-yl)-N-(2-((1,2,3,4-tetrahydroacridin9-yl)amino)ethyl)acrylamide (19). ${ }^{45}$ According to the procedure used to synthesize 8, 19 was synthesized from $(E)$-3-(benzo[ $d]$ [1,3]dioxol-5-yl)acrylic acid (0.16 g, $0.83 \mathrm{mmol})$ to give a white powder $0.21 \mathrm{~g}$ (60.99\%). Mp 197-199 ${ }^{\circ} \mathrm{C} .{ }^{1} \mathrm{H}$ NMR $(300 \mathrm{MHz}$, DMSO- $d 6): \delta 8.48-8.42(\mathrm{~m}, 2 \mathrm{H}, \mathrm{ArH}), 7.95$ (br, $1 \mathrm{H}, \mathrm{CONH}), 7.80-$ $7.77(\mathrm{~m}, 2 \mathrm{H}, \operatorname{ArH}), 7.56(\mathrm{t}, J=7.32 \mathrm{~Hz}, 1 \mathrm{H}, \operatorname{ArH}) 7.35(\mathrm{~d}, J=$ $15.69 \mathrm{~Hz}, 1 \mathrm{H}, \mathrm{COCH}=\mathrm{CH}), 7.14(\mathrm{~s}, 1 \mathrm{H}, \mathrm{NH}), 7.06(\mathrm{~d}, J=7.98 \mathrm{~Hz}$, $1 \mathrm{H}, \operatorname{ArH}), 6.94$ (d, $J=7.98 \mathrm{~Hz}, 1 \mathrm{H}, \operatorname{ArH}), 6.41$ (d, $J=15.72 \mathrm{~Hz}$, $1 \mathrm{H}, \mathrm{COC} \underline{\mathrm{H}}=\mathrm{CH}), 6.05\left(\mathrm{~s}, 2 \mathrm{H}, \mathrm{OCH}_{2} \mathrm{O}\right), 4.00(\mathrm{~d}, J=4.71 \mathrm{~Hz}, 2 \mathrm{H}$, ${\mathrm{NHC} \underline{\mathrm{H}_{2}}}$ ), 3.55 (d, $\left.J=5.34 \mathrm{~Hz}, 2 \mathrm{H}, \mathrm{C}_{2} \mathrm{NHCO}\right), 2.94$ (br, $2 \mathrm{H}$, C4- $\underline{\mathrm{H}_{2}}$ ), 2.69 (br, 2H, C1- $\underline{\mathrm{H}_{2}}$ ), $1.82\left(\mathrm{br}, 4 \mathrm{H}, \mathrm{C} 2-\underline{\mathrm{H}_{2}}\right.$ and $\mathrm{C} 3-\underline{\mathrm{H}_{2}}$ ). ${ }^{13} \mathrm{C}$ NMR (125 MHz, DMSO-d6): $\delta 167.25,156.50,151.05,149.12$, 148.43, 139.75, 138.45, 133.19, 129.47, 125.76, 125.53, 123.96, $119.81,119.64,116.00,111.89$, 109.07, 106.70, 101.97, 48.87, 28.46, 24.21, 21.91, 20.80. HRMS (ESI): calcd for $\mathrm{C}_{25} \mathrm{H}_{25} \mathrm{~N}_{3} \mathrm{O}_{3}[\mathrm{M}$ $+\mathrm{H}]^{+}$416.1969, found 416.1964. HPLC (70\% methanol in water with $\left.0.5 \% \mathrm{H}_{3} \mathrm{PO}_{4}\right): t_{\mathrm{R}}=3.44 \mathrm{~min}, 98.605 \%$.

(E)-3-(2-Chlorophenyl)- $N-(2-((1,2,3,4$-tetrahydroacridin-9-yl)amino)ethyl)acrylamide (20). According to the procedure used to synthesize 8, 20 was synthesized from (E)-3-(2-chlorophenyl)acrylic acid $(0.15 \mathrm{~g}, 0.83 \mathrm{mmol})$ to give a yellow powder $0.18 \mathrm{~g}$ (53.51\%). Mp 201-203 ${ }^{\circ} \mathrm{C}$. ${ }^{1} \mathrm{H}$ NMR $(300 \mathrm{MHz}$, DMSO- $d 6): \delta 8.60(\mathrm{t}, J=5.70 \mathrm{~Hz}, 1 \mathrm{H}, \mathrm{ArH}), 8.47(\mathrm{~d}, J=8.64 \mathrm{~Hz}$, 1H, ArH) 7.89-7.84 (m, 2H, CONH and ArH), 7.80-7.66 (m, $3 \mathrm{H}, \mathrm{ArH}$ and $\mathrm{COCH}=\mathrm{CH}), 7.60-7.51(\mathrm{~m}, 2 \mathrm{H}, \mathrm{ArH}), 7.43-7.38$ $(\mathrm{m}, 2 \mathrm{H}, \mathrm{ArH}$ and $\mathrm{NH}), 6.60(\mathrm{~d}, J=15.69 \mathrm{~Hz}, 1 \mathrm{H}, \mathrm{COC} \underline{\mathrm{H}}=\mathrm{CH})$, $4.02\left(\mathrm{~d}, J=5.31 \mathrm{~Hz}, 2 \mathrm{H}, \mathrm{NHC}_{2}\right), 3.58(\mathrm{~d}, J=5.67 \mathrm{~Hz}, 2 \mathrm{H}$, $\mathrm{C} \mathrm{H}_{2} \mathrm{NHCO}$ ), 2.94 (br, 2H, C4- $-\mathrm{H}_{2}$ ), 2.67 (br, 2H, C1- $\mathrm{H}_{2}$ ), 1.83 (br, $4 \mathrm{H}, \mathrm{C} 2-\underline{\mathrm{H}_{2}}$ and $\left.\mathrm{C} 3-\underline{\mathrm{H}_{2}}\right) \cdot{ }^{13} \mathrm{C}$ NMR (125 MHz, DMSO-d6): $\delta 166.36,156.71,151.06,138.33,135.12,133.80,133.32$,
132.97, 131.60, 130.50, 128.32, 128.13, 125.77, 125.64, 125.01, 119.56, 116.05, 112.01, 48.51, 28.45, 24.24, 21.92, 20.81. HRMS (ESI): calcd for $\mathrm{C}_{24} \mathrm{H}_{24} \mathrm{ClN}_{3} \mathrm{O}[\mathrm{M}+\mathrm{H}]^{+} 406.1681$, found 406.1675. HPLC (70\% methanol in water with $\left.0.5 \% \mathrm{H}_{3} \mathrm{PO}_{4}\right)$ : $t_{\mathrm{R}}=4.69 \min , 97.027 \%$.

(E)-3-(3-Chlorophenyl)-N-(2-((1,2,3,4-tetrahydroacridin-9-yl)amino)ethyl)acrylamide (21). According to the procedure used to synthesize 8, 21 was synthesized from (E)-3-(3-chlorophenyl)acrylic acid $(0.15 \mathrm{~g}, 0.83 \mathrm{mmol})$ to give a yellow powder $0.17 \mathrm{~g}$ (50.53\%). Mp 192-193 ${ }^{\circ} \mathrm{C} .{ }^{1} \mathrm{H}$ NMR $(300 \mathrm{MHz}$, DMSO-d6): $\delta 8.50-8.45(\mathrm{~m}, 2 \mathrm{H}, \mathrm{ArH}) 7.94-7.78(\mathrm{~m}, 2 \mathrm{H}, \mathrm{CONH}$ and $\mathrm{ArH}), 7.78(\mathrm{~d}, J=8.07 \mathrm{~Hz}, 1 \mathrm{H}, \mathrm{ArH}) 7.62-7.51(\mathrm{~m}, 3 \mathrm{H}, \mathrm{ArH}$ and $\mathrm{COCH}=\mathrm{CH}), 7.44-7.39(\mathrm{~m}, 3 \mathrm{H}, \mathrm{ArH}$ and $\mathrm{NH}), 6.63(\mathrm{~d}, J=$ $15.81 \mathrm{~Hz}, 1 \mathrm{H}, \mathrm{COC} \underline{\mathrm{H}}=\mathrm{CH}), 4.02\left(\mathrm{~d}, J=4.80 \mathrm{~Hz}, 2 \mathrm{H}, \mathrm{NHC}_{\underline{\mathrm{H}_{2}}}\right)$, $3.57\left(\mathrm{~d}, J=5.31 \mathrm{~Hz}, 2 \mathrm{H}, \mathrm{C} \mathrm{H}_{2} \mathrm{NHCO}\right), 2.95$ (br, $2 \mathrm{H}, \mathrm{C} 4-\overline{\mathrm{H}_{2}}$ ),

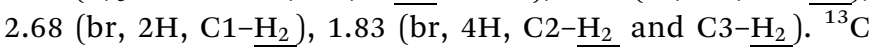
NMR (125 MHz, DMSO-d6): $\delta 166.59,15 \overline{6.65}, 150.99,138.32$, 137.43, 134.17, 133.34, 131.29, 129.78, 127.77, 126.56, 125.80, $125.61,123.51,119.52,115.96,111.91,48.61,28.39,24.20$, 21.89, 20.78. HRMS (ESI): calcd for $\mathrm{C}_{24} \mathrm{H}_{24} \mathrm{ClN}_{3} \mathrm{O}[\mathrm{M}+\mathrm{H}]^{+}$ 406.1681, found 406.1671. HPLC (70\% methanol in water with $\left.0.5 \% \mathrm{H}_{3} \mathrm{PO}_{4}\right): t_{\mathrm{R}}=5.15 \mathrm{~min}, 95.756 \%$.

(E)-3-(4-Chlorophenyl)-N-(2-((1,2,3,4-tetrahydroacridin-9-yl)amino)ethyl)acrylamide (22). According to the procedure used to synthesize 8, 22 was synthesized from (E)-3-(4-chlorophenyl) acrylic acid ( $0.15 \mathrm{~g}, 0.83 \mathrm{mmol})$ to give a yellow powder $0.2 \mathrm{~g}$ (59.45\%). Mp 200-202 ${ }^{\circ} \mathrm{C} .{ }^{1} \mathrm{H}$ NMR (300 MHz, DMSO- $\left.d 6\right): \delta 8.52-$ 8.45 (m, 2H, ArH), 7.95 (br, 1H, CONH), 7.89-7.76 (m, 2H, ArH and $\mathrm{COCH}=\mathrm{CH}), 7.57(\mathrm{br}, 2 \mathrm{H}, \mathrm{ArH}$ and $\mathrm{NH}), 7.48-7.40(\mathrm{~m}, 3 \mathrm{H}$, $\mathrm{ArH}), 6.57$ (d, $J=15.81 \mathrm{~Hz}, 1 \mathrm{H}, \mathrm{COC} \underline{\mathrm{H}}=\mathrm{CH}), 4.02(\mathrm{~d}, J=$ $5.07 \mathrm{~Hz}, 2 \mathrm{H}, \mathrm{NHC}_{2}$ ), 3.57 (d, $J=5.37 \mathrm{~Hz}, 2 \mathrm{H}, \mathrm{C} \mathrm{H}_{2} \mathrm{NHCO}$ ), 2.94 (br, 2H, C4- $\underline{\mathrm{H}}_{2}$ ), 2.68 (br, 2H, C1- $\underline{\mathrm{H}_{2}}$ ), 1.83 (br, 4H, C2- $\underline{-\mathrm{H}_{2}}$ and $\mathrm{C} 3-\underline{\mathrm{H}_{2}}$ ). ${ }^{13} \mathrm{C} \mathrm{NMR}$ (125 MHz, DMSO-d6): $\delta$ 166.72, 156.63, 150.96, 138.53, 134.59, 134.08, 133.31, 129.80, 129.50, 125.80, $125.60,122.61,119.59,116.00,111.94,48.65,28.43,24.21$, 21.90, 20.79. HRMS (ESI): calcd for $\mathrm{C}_{24} \mathrm{H}_{24} \mathrm{ClN}_{3} \mathrm{O}[\mathrm{M}+\mathrm{H}]^{+}$ 406.1681, found 406.1673. HPLC (70\% methanol in water with $\left.0.5 \% \mathrm{H}_{3} \mathrm{PO}_{4}\right): t_{\mathrm{R}}=5.23 \mathrm{~min}, 95.101 \%$.

(E)-3-(4-Fluorophenyl)- $N$-(2-((1,2,3,4-tetrahydroacridin-9-yl)amino)ethyl)acrylamide (23). According to the procedure used to synthesize 8, 23 was synthesized from (E)-3-(4-fluorophenyl) acrylic acid $(0.14 \mathrm{~g}, 0.83 \mathrm{mmol})$ to give a white powder $0.14 \mathrm{~g}$ (43.37\%). Mp 198-199 ${ }^{\circ} \mathrm{C} .{ }^{1} \mathrm{H}$ NMR (300 MHz, DMSO- $\left.d 6\right): \delta 8.50-$ 8.45 (m, 2H, ArH), 7.96 (br, 1H, CONH), 7.89-7.76 (m, 2H, ArH), 7.64-7.55 (m, 3H, ArH and NH), $7.43(\mathrm{~d}, J=15.78 \mathrm{~Hz}, 1 \mathrm{H}$, $\mathrm{COCH}=\mathrm{CH}), 7.24(\mathrm{t}, J=8.64 \mathrm{~Hz}, 2 \mathrm{H}, \mathrm{ArH}), 6.52(\mathrm{~d}, J=15.81 \mathrm{~Hz}$, $1 \mathrm{H}, \mathrm{COC} \underline{\mathrm{H}}=\mathrm{CH}), 4.02\left(\mathrm{~d}, J=4.80 \mathrm{~Hz}, 2 \mathrm{H}, \mathrm{NHC}_{2}\right), 3.57(\mathrm{~d}, J=$ $5.07 \mathrm{~Hz}, 2 \mathrm{H}, \mathrm{C} \mathrm{H}_{2} \mathrm{NHCO}$ ), 2.94 (br, 2H, C4 $-\underline{\mathrm{H}_{2}}$ ), 2.68 (br, $2 \mathrm{H}$, $\mathrm{C} 1-\underline{\mathrm{H}_{2}}$ ), 1.83 (br, 4H, C2 $-\underline{\mathrm{H}_{2}}$ and $\left.\mathrm{C} 3-\underline{\mathrm{H}_{2}}\right) .{ }^{13} \mathrm{C} \mathrm{NMR}(125 \mathrm{MHz}$, DMSO- $d 6): \delta$ 166.90, 164.09, 162.45, 156.65, 150.96, 138.71, $138.30,133.32$, 131.74, 130.28, 125.69, 121.68, 119.51, 116.51, 116.36, 115.95, 111.88, 48.74, 46.22, 28.38, 24.19, 21.89, 20.77. HRMS (ESI): calcd for $\mathrm{C}_{24} \mathrm{H}_{24} \mathrm{FN}_{3} \mathrm{O}[\mathrm{M}+\mathrm{H}]^{+} 390.1976$, found 390.1968. HPLC (70\% methanol in water with $\left.0.5 \% \mathrm{H}_{3} \mathrm{PO}_{4}\right): t_{\mathrm{R}}=$ $5.30 \mathrm{~min}, 95.458 \%$.

(E)-3-(4-Bromophenyl)-N-(2-((1,2,3,4-tetrahydroacridin-9-yl)amino)ethyl)acrylamide (24). According to the procedure used to 
synthesize 8, 24 was synthesized from (E)-3-(4-bromophenyl) acrylic acid $(0.19 \mathrm{~g}, 0.83 \mathrm{mmol})$ to give a brown powder $0.19 \mathrm{~g}$ (50.91\%). Mp 203-205 ${ }^{\circ} \mathrm{C} .{ }^{1} \mathrm{H}$ NMR (300 MHz, DMSO- $\left.d 6\right): \delta 8.53$ (br, $1 \mathrm{H}, \mathrm{ArH}), 8.41$ (d, J=8.61 Hz, 1H, ArH), 7.79 (br, 2H, CONH and $\mathrm{ArH}), 7.62(\mathrm{~d}, J=8.31 \mathrm{~Hz}, 2 \mathrm{H}, \mathrm{ArH}), 7.52(\mathrm{~d}, J=8.25 \mathrm{~Hz}, 4 \mathrm{H}$, ArH and $\mathrm{NH}), 7.41(\mathrm{~d}, J=15.59 \mathrm{~Hz}, 1 \mathrm{H}, \mathrm{COCH}=\mathrm{CH}), 6.60(\mathrm{~d}, J=$ $15.81 \mathrm{~Hz}, 1 \mathrm{H}, \mathrm{COC} \underline{\mathrm{H}}=\mathrm{CH}), 3.93\left(\mathrm{~d}, J=5.70 \mathrm{~Hz}, 2 \mathrm{H}, \mathrm{NHC}_{2}\right)$, 3.55 (d, $J=5.34 \mathrm{~Hz}, 2 \mathrm{H}, \mathrm{C} \mathrm{H}_{2} \mathrm{NHCO}$ ), 2.94 (br, 2H, C4- $\mathrm{H}_{2}$ ), 2.69 (br, 2H, C1- $\underline{\mathrm{H}}_{2}$ ), 1.82 (br, $4 \mathrm{H}, \mathrm{C} 2-\underline{\mathrm{H}_{2}}$ and C3- $\left.\underline{\mathrm{H}}_{2}\right) .{ }^{13} \mathrm{C} \mathrm{NMR}(125$ MHz, DMSO-d6): $\delta$ 166.05, 158.46, 156.65, 150.59, 147.47, 138.16, 134.62, 132.33, 129.93, 128.84, 128.31, 123.75, 123.47, 123.27, 123.13, 120.60, 116.41, 116.36, 48.63, 46.20, 34.05, 25.48, 23.26, 22.93. HRMS (ESI): calcd for $\mathrm{C}_{24} \mathrm{H}_{24} \mathrm{BrN}_{3} \mathrm{O}[\mathrm{M}+\mathrm{H}]^{+}$ 450.1176, found 450.1181. HPLC (70\% methanol in water with $\left.0.5 \% \mathrm{H}_{3} \mathrm{PO}_{4}\right): t_{\mathrm{R}}=5.79 \mathrm{~min}, 95.458 \%$.

(E)-N-(2-((1,2,3,4-Tetrahydroacridin-9-yl)amino)ethyl)-3-(2-(trifluoromethyl)phenyl)acrylamide (25). According to the procedure used to synthesize 8, 25 was synthesized from (E)-3-(2-(trifluoromethyl)phenyl)acrylic acid $(0.18 \mathrm{~g}, 0.83 \mathrm{mmol})$ to give a white powder $0.22 \mathrm{~g}$ (60.41\%). Mp 183-184 ${ }^{\circ} \mathrm{C} .{ }^{1} \mathrm{H}$ NMR $(300$ MHz, DMSO- $d 6): \delta 8.62(\mathrm{t}, J=5.43 \mathrm{~Hz}, 1 \mathrm{H}, \operatorname{ArH}), 8.46(\mathrm{~d}, J=$ $8.7 \mathrm{~Hz}, 1 \mathrm{H}, \mathrm{ArH}) 7.89-7.84(\mathrm{~m}, 2 \mathrm{H}, \mathrm{CONH}$ and ArH), 7.80-7.73 $(\mathrm{m}, 4 \mathrm{H}, \mathrm{ArH}$ and $\mathrm{COCH}=\mathrm{CH}), 7.70-7.68(\mathrm{~m}, 1 \mathrm{H}, \mathrm{ArH}), 7.62-7.55$ $(\mathrm{m}, 2 \mathrm{H}, \mathrm{ArH}$ and $\mathrm{NH}), 6.62(\mathrm{~d}, J=15.60 \mathrm{~Hz}, 1 \mathrm{H}, \mathrm{COCH}=\mathrm{CH})$, $4.03\left(\mathrm{~d}, J=5.40 \mathrm{~Hz}, 2 \mathrm{H}, \mathrm{NHCH}_{2}\right.$ ), 3.59 (d, $J=5.76 \mathrm{~Hz}, 2 \mathrm{H}$, $\mathrm{C} \mathrm{H}_{2} \mathrm{NHCO}$ ), 2.95 (br, 2H, C4- $-\overline{\mathrm{H}_{2}}$ ), 2.67 (br, 2H, C1- $-\mathrm{H}_{2}$ ), 1.83 (br, 4H, C2- $\mathrm{H}_{2}$ and $\mathrm{C} 3-\underline{\mathrm{H}_{2}}$ ). ${ }^{13} \mathrm{C}$ NMR (125 MHz, DMSO-d6): $\delta 165.95,156.56,138.43,134.64,133.61,133.26,130.23,128.30$, $127.40,127.20,126.64,126.41,125.74,125.59,123.73,119.66$, $48.40,46.33,28.47,26.41,26.38,24.23,21.88,20.78$. HRMS (ESI): calcd for $\mathrm{C}_{25} \mathrm{H}_{24} \mathrm{~F}_{3} \mathrm{~N}_{3} \mathrm{O}[\mathrm{M}+\mathrm{H}]^{+} 440.1944$, found 440.1936 . HPLC $\left(70 \%\right.$ methanol in water with $\left.0.5 \% \mathrm{H}_{3} \mathrm{PO}_{4}\right): t_{\mathrm{R}}=4.72 \mathrm{~min}$, $97.899 \%$.

(E)-N-(2-((1,2,3,4-Tetrahydroacridin-9-yl)amino)ethyl)-3-(4-(trifluoromethyl)phenyl)acrylamide (26). According to the procedure used to synthesize 8, 26 was synthesized from (E)-3-(4-(trifluoromethyl)phenyl)acrylic acid $(0.18 \mathrm{~g}, 0.83 \mathrm{mmol})$ to give a white powder $0.18 \mathrm{~g}(49.42 \%)$. Mp $182-184{ }^{\circ} \mathrm{C} .{ }^{1} \mathrm{H}$ NMR $(300$ MHz, DMSO-d6): $\delta 8.62$ (br, $1 \mathrm{H}, \mathrm{ArH}), 8.47$ (d, $J=8.61 \mathrm{~Hz}, 1 \mathrm{H}$, $\mathrm{ArH}), 7.92-7.84(\mathrm{~m}, 2 \mathrm{H}, \mathrm{CONH}$ and $\mathrm{ArH}), 7.77$ (br, 4H, ArH and $\mathrm{NH}), 7.58$ (t, $J=7.44 \mathrm{~Hz}, 1 \mathrm{H}, \mathrm{ArH}), 7.50$ (d, $J=15.84 \mathrm{~Hz}, 1 \mathrm{H}$, $\mathrm{COCH}=\mathrm{CH}), 6.62(\mathrm{~d}, J=15.60 \mathrm{~Hz}, 1 \mathrm{H}, \mathrm{COCH}=\mathrm{CH}), 4.03(\mathrm{~d}, J=$ $5.40 \mathrm{~Hz}, 2 \mathrm{H}, \mathrm{NHC} \mathrm{H}_{2}$ ), 3.59 (d, $J=5.76 \mathrm{~Hz}, 2 \mathrm{H}, \mathrm{C} \mathrm{H}_{2} \mathrm{NHCO}$ ), 2.95 (br, 2H, C4 $-\mathrm{H}_{2}$ ), 2.67 (br, $2 \mathrm{H}, \mathrm{C} 1-\mathrm{H}_{2}$ ), 1.83 (br, $\overline{4 \mathrm{H}}, \mathrm{C} 2-\mathrm{H}_{2}$ and $\left.\mathrm{C} 3-\mathrm{H}_{2}\right) .{ }^{13} \mathrm{C} \mathrm{NMR}$ (125 MHz, DMSO- $\left.d 6\right): \delta$ 166.40, 156.60, 151.16, 139.21, 133.28, 138.38, 138.16, 133.28, 128.72, 126.34, 126.31, 125.76, 125.60, 125.45, 124.65, 123.65, 119.61, 116.02, 111.96, 48.50, 28.44, 24.24, 21.90, 20.80. HRMS (ESI): calcd for $\mathrm{C}_{25} \mathrm{H}_{24} \mathrm{~F}_{3} \mathrm{~N}_{3} \mathrm{O}[\mathrm{M}+\mathrm{H}]^{+} 440.1944$, found 440.1948. HPLC (70\% methanol in water with $\left.0.5 \% \mathrm{H}_{3} \mathrm{PO}_{4}\right): t_{\mathrm{R}}=5.36 \mathrm{~min}, 98.618 \%$.

(E)-3-(2-Nitrophenyl)-N-(2-((1,2,3,4-tetrahydroacridin-9-yl)amino)ethyl)acrylamide (27). According to the procedure used to synthesize 8, 27 was synthesized from (E)-3-(2-nitrophenyl)acrylic acid $(0.16 \mathrm{~g}, 0.83 \mathrm{mmol})$ to give a yellow powder $0.23 \mathrm{~g}(66.64 \%)$. Mp 216-218 ${ }^{\circ} \mathrm{C} .{ }^{1} \mathrm{H}$ NMR (300 MHz, DMSO- $\left.d 6\right): \delta 8.63(\mathrm{br}, 1 \mathrm{H}$, $\operatorname{ArH}), 8.45$ (d, $J=8.55 \mathrm{~Hz}, 1 \mathrm{H}, \operatorname{ArH}), 8.25$ (d, $J=8.70 \mathrm{~Hz}, 2 \mathrm{H}, \operatorname{ArH})$, 7.87-7.76 (m, 4H, CONH and ArH and NH), 7.59-7.51 (m, 2H, ArH and $\mathrm{COCH}=\mathrm{C} \underline{\mathrm{H}}), 6.65(\mathrm{~d}, J=15.84 \mathrm{~Hz}, 1 \mathrm{H}, \mathrm{COC} \underline{\mathrm{H}}=\mathrm{CH}), 4.00(\mathrm{~d}$, $\left.J=4.62 \mathrm{~Hz}, 2 \mathrm{H}, \mathrm{NHC}_{2}\right), 3.57\left(\mathrm{~d}, J=5.64 \mathrm{~Hz}, 2 \mathrm{H}, \mathrm{C}_{2} \mathrm{NHCO}\right)$, 2.94 (br, 2H, C4- $\underline{\mathrm{H}}_{2}$ ), 2.68 (br, 2H, C1- $\mathrm{H}_{2}$ ), 1.83 (br, $4 \mathrm{H}, \mathrm{C} 2-\underline{\mathrm{H}_{2}}$ and $\left.\mathrm{C} 3-\mathrm{H}_{2}\right) .{ }^{13} \mathrm{C} \mathrm{NMR}(125 \mathrm{MHz}, \mathrm{DMSO}-d 6): \delta 166.01,156 . \overline{51}$, $151.16,148.77,138.53,135.02,134.38,133.23,130.90,130.30$, 129.21, 126.44, 125.75, 125.59, 125.16, 119.76, 116.08, 112.07, $48.48,28.53,24.21,21.91,20.82$. HRMS (ESI): calcd for $\mathrm{C}_{24} \mathrm{H}_{24} \mathrm{~N}_{4} \mathrm{O}_{3}[\mathrm{M}+\mathrm{H}]^{+}$417.1921, found 417.192. HPLC (70\% methanol in water with $\left.0.5 \% \mathrm{H}_{3} \mathrm{PO}_{4}\right): t_{\mathrm{R}}=2.97 \mathrm{~min}, 99.720 \%$.

(E)-3-(3-Nitrophenyl)-N-(2-((1,2,3,4-tetrahydroacridin-9-yl)amino)ethyl)acrylamide (28). According to the procedure used to synthesize 8, 28 was synthesized from (E)-3-(3-nitrophenyl)acrylic acid $(0.16 \mathrm{~g}, 0.83 \mathrm{mmol})$ to give a yellow powder $0.22 \mathrm{~g}(63.74 \%)$. Mp 210-213 ${ }^{\circ} \mathrm{C} .{ }^{1} \mathrm{H}$ NMR (300 MHz, DMSO- $\left.d 6\right): \delta 8.57(\mathrm{t}, J=$ $5.55 \mathrm{~Hz}, 1 \mathrm{H}, \mathrm{ArH}), 8.47$ (d, $J=8.76 \mathrm{~Hz}, 1 \mathrm{H}, \operatorname{ArH}), 8.37$ (s, $1 \mathrm{H}$, $\mathrm{CONH}), 8.21$ (d, $J=6.87 \mathrm{~Hz}, 1 \mathrm{H}, \operatorname{ArH}), 8.01(\mathrm{~d}, J=7.86 \mathrm{~Hz}, 1 \mathrm{H}$, ArH) 7.94 (br, 1H, NH), 7.87 (t, $J=7.59 \mathrm{~Hz}, 1 \mathrm{H}, \operatorname{ArH}), 7.77$ (d, $J=$ $8.43 \mathrm{~Hz}, 1 \mathrm{H}, \mathrm{ArH}), 7.70$ (t, J=8.00 Hz, 1H, ArH), 7.60-7.53 (m, 2H, $\mathrm{ArH}$ and $\mathrm{COCH}=\mathrm{CH}), 6.75(\mathrm{~d}, J=15.81 \mathrm{~Hz}, 1 \mathrm{H}, \mathrm{COCH}=\mathrm{CH})$, $4.03\left(\mathrm{~d}, J=5.31 \mathrm{~Hz}, 2 \mathrm{H}, \mathrm{NHC} \mathrm{H}_{2}\right.$ ), 3.59 (d, $J=5.58 \mathrm{~Hz}, 2 \mathrm{H}$, $\mathrm{C} \mathrm{H}_{2} \mathrm{NHCO}$ ), 2.94 (br, 2H, C4- $\mathrm{H}_{2}$ ), 2.68 (br, 2H, C1- $\mathrm{H}_{2}$ ), 1.83 (br, $4 \mathrm{H}, \mathrm{C} 2-\mathrm{H}_{2}$ and $\left.\mathrm{C} 3-\mathrm{H}_{2}\right) .{ }^{13} \mathrm{C} \mathrm{NMR}(125 \mathrm{MHz}$, DMSO- $d 6): \delta$ 166.25, $156.54,151.16,148.76,137.46,137.01,134.38,133.22,131.02$, $125.76,125.59,124.80,124.40,122.16,119.59,116.03,111.94$, $48.40,28.41,24.24,21.92,20.78$. HRMS (ESI): calcd for $\mathrm{C}_{24} \mathrm{H}_{24} \mathrm{~N}_{4} \mathrm{O}_{3}[\mathrm{M}+\mathrm{H}]^{+}$417.1921, found 417.1921. HPLC $(70 \%$ methanol in water with $\left.0.5 \% \mathrm{H}_{3} \mathrm{PO}_{4}\right): t_{\mathrm{R}}=3.19 \mathrm{~min}, 98.916 \%$.

(E)-3-(4-Nitrophenyl)-N-(2-((1,2,3,4-tetrahydroacridin-9-yl)amino)ethyl)acrylamide (29). According to the procedure used to synthesize 8, 29 was synthesized from (E)-3-(4-nitrophenyl)acrylic acid $(0.16 \mathrm{~g}, 0.83 \mathrm{mmol})$ to give a yellow powder $0.24 \mathrm{~g}(69.54 \%)$. Mp 215-217 ${ }^{\circ} \mathrm{C} .{ }^{1} \mathrm{H}$ NMR (300 MHz, DMSO-d6): $\delta 8.64(\mathrm{br}, 1 \mathrm{H}$, ArH), 8.46 (d, $J=8.73 \mathrm{~Hz}, 1 \mathrm{H}, \operatorname{ArH}), 8.04$ (d, $J=7.92 \mathrm{~Hz}, 1 \mathrm{H}, \operatorname{ArH})$, $7.86(\mathrm{t}, J=7.25 \mathrm{~Hz}, 2 \mathrm{H}, \mathrm{CONH}$ and $\mathrm{ArH}), 7.79-7.74(\mathrm{~m}, 3 \mathrm{H}, \mathrm{ArH}$ and $\mathrm{COCH}=\mathrm{CH}), 7.68-7.55(\mathrm{~m}, 3 \mathrm{H}, \mathrm{ArH}$ and $\mathrm{NH}), 6.55(\mathrm{~d}, J=$ $15.54 \mathrm{~Hz}, 1 \mathrm{H}, \mathrm{COC} \underline{\mathrm{H}}=\mathrm{CH}), 4.02\left(\mathrm{~d}, J=5.43 \mathrm{~Hz}, 2 \mathrm{H}, \mathrm{NHC}_{2}\right)$, $3.59\left(\mathrm{~d}, J=5.58 \mathrm{~Hz}, 2 \mathrm{H}, \mathrm{C} \mathrm{H}_{2} \mathrm{NHCO}\right), 2.96$ (br, $\left.2 \mathrm{H}, \mathrm{C} 4-\underline{\mathrm{H}_{2}}\right), 2.67$ (br, 2H, C1- $\underline{\mathrm{H}_{2}}$ ), 1.83 (br, $4 \overline{\mathrm{H}}, \mathrm{C} 2-\underline{\mathrm{H}_{2}}$ and $\left.\mathrm{C} 3-\underline{\mathrm{H}_{2}}\right) .{ }^{13} \mathrm{C} \mathrm{NMR}(125$ MHz, DMSO- $d 6): \delta 166.14,156.43,151.24,148.06,141.68,138.55$, 137.43 , 133.16, 129.13, 126.08, 125.68, 125.55, 124.59, 123.22, $119.80,116.09,112.05,48.43,28.56,24.26,21.92$, 20.84. HRMS (ESI): calcd for $\mathrm{C}_{24} \mathrm{H}_{24} \mathrm{~N}_{4} \mathrm{O}_{3}[\mathrm{M}+\mathrm{H}]^{+}$417.1921, found 417.1914. HPLC (70\% methanol in water with $\left.0.5 \% \mathrm{H}_{3} \mathrm{PO}_{4}\right): t_{\mathrm{R}}=3.27 \mathrm{~min}$, $97.468 \%$.

(E)-3-(4-Chloro-3-nitrophenyl)-N-(2-((1,2,3,4-tetrahydroacridin-9$y$ l)amino)ethyl)acrylamide (30). According to the procedure used to synthesize 8, 30 was synthesized from (E)-3-(4-chloro-3nitrophenyl)acrylic acid $(0.19 \mathrm{~g}, 0.83 \mathrm{mmol})$ to give a white powder $0.19 \mathrm{~g}$ (50.84\%). Mp 208-210 ${ }^{\circ} \mathrm{C} .{ }^{1} \mathrm{H}$ NMR $(300 \mathrm{MHz}$, DMSO- $d 6): \delta 8.56$ (br, $1 \mathrm{H}, \mathrm{ArH}), 8.47$ (d, $J=8.55 \mathrm{~Hz}, 1 \mathrm{H}, \operatorname{ArH}$ ), 8.30-8.26 (m, 1H, ArH), 7.92-7.77 (m, 5H, CONH and ArH and $\mathrm{NH}), 7.58(\mathrm{t}, J=7.52 \mathrm{~Hz}, 1 \mathrm{H}, \mathrm{ArH}), 7.48(\mathrm{~d}, J=15.87 \mathrm{~Hz}, 1 \mathrm{H}$, $\mathrm{COCH}=\mathrm{C} \underline{\mathrm{H}}), 6.71(\mathrm{~d}, J=15.84 \mathrm{~Hz}, 1 \mathrm{H}, \mathrm{COC} \underline{\mathrm{H}}=\mathrm{CH}), 4.02(\mathrm{~d}, J=$ $5.52 \mathrm{~Hz}, 2 \mathrm{H}, \mathrm{NHC}_{2}$ ), 3.58 (d, $J=5.64 \mathrm{~Hz}, 2 \mathrm{H}, \mathrm{C} \mathrm{H}_{2} \mathrm{NHCO}$ ), 2.95 (br, 2H, C4- $\mathrm{H}_{2}$ ), 2.68 (br, 2H, C1- $\mathrm{H}_{2}$ ), 1.83 (br, 4H, C2- $-\underline{\mathrm{H}_{2}}$ and $\mathrm{C} 3-\underline{\mathrm{H}_{2}}$ ). ${ }^{13} \mathrm{C}$ NMR (125 MHz, DMSO-d6): $\delta$ 166.16, 156.61, 151.00 , 148.44, 138.28, 136.52, 135.84, 133.31, 132.79, 132.64, 
$125.76,125.60,125.25,124.67,119.52,115.94,111.91,48.47$, $46.34,28.39,24.21,21.88,20.78$. HRMS (ESI): calcd for $\mathrm{C}_{24} \mathrm{H}_{24} \mathrm{ClN}_{4} \mathrm{O}_{3}[\mathrm{M}+\mathrm{H}]^{+}$451.1532, found 451.1528. HPLC (70\% methanol in water with $\left.0.5 \% \mathrm{H}_{3} \mathrm{PO}_{4}\right): t_{\mathrm{R}}=4.23 \mathrm{~min}, 98.389 \%$.

(E)-N-(2-((1,2,3,4-Tetrahydroacridin-9-yl)amino)ethyl)-3-(4-(trifluoromethoxy)phenyl)acrylamide (31). According to the procedure used to synthesize 8, 31 was synthesized from (E)-3-(4-(trifluoromethoxy)phenyl)acrylic acid $(0.19 \mathrm{~g}, 0.83 \mathrm{mmol})$ to give a white powder $0.13 \mathrm{~g}$ (34.44\%). Mp 188-189 ${ }^{\circ} \mathrm{C}$. ${ }^{1} \mathrm{H}$ NMR (300 MHz, DMSO- $d 6): \delta$ 8.54-8.48 (m, 2H, ArH), 7.94-7.79 (m, 3H, $\mathrm{CONH}$ and $\mathrm{ArH}), 7.56-7.38(\mathrm{~m}, 5 \mathrm{H}, \mathrm{ArH}$ and $\mathrm{NH}$ and $\mathrm{COCH}=\mathrm{CH})$, 6.70-6.62 (m, 1H, COC $\underline{\mathrm{H}}=\mathrm{CH}), 4.02\left(\mathrm{br}, 2 \mathrm{H}, \mathrm{NHC}_{2}\right.$ ), $3.58(\mathrm{br}$, 2H, $\mathrm{C} \mathrm{H}_{2} \mathrm{NHCO}$ ), 2.95 (br, 2H, C4- $\mathrm{H}_{2}$ ), 2.68 (br, 2H, C1- $\mathrm{H}_{2}$ ), 1.82 (br, 4 $\overline{\mathrm{H}}, \mathrm{C} 2-\underline{\mathrm{H}_{2}}$ and $\mathrm{C} 3-\mathrm{H}_{2}$ ). ${ }^{13} \mathrm{C} \mathrm{NMR}$ (125 MHz, DMSO-d6): $\delta$ 166.51, 156.62 $, 151.02, \overline{149.28}, 138.33,138.18,137.65,133.32$, $131.47,127.10,125.78,125.60,123.85,122.37,121.38,120.28$, 119.68, 119.55, 115.97, 111.92, 48.59, 28.41, 24.20, 21.89, 20.78. HRMS (ESI): calcd for $\mathrm{C}_{25} \mathrm{H}_{24} \mathrm{FN}_{3} \mathrm{O}_{2}[\mathrm{M}+\mathrm{H}]^{+} 456.1893$, found 456.1886. HPLC (70\% methanol in water with $\left.0.5 \% \mathrm{H}_{3} \mathrm{PO}_{4}\right): t_{\mathrm{R}}=$ $6.05 \mathrm{~min}, 98.933 \%$.

(E)-Methyl-(4-(3-oxo-3-((2-((1,2,3,4-tetrahydroacridin-9-yl)amino)ethyl)amino)prop-1-en-1-yl)phenyl)-carbonate (32). According to the procedure used to synthesize 8, 32 was synthesized from $(E)$-3-(4((methoxycarbonyl)oxy)phenyl)acrylic acid ( $0.18 \mathrm{~g}, 0.83 \mathrm{mmol})$ to give a white powder $0.2 \mathrm{~g}(54.17 \%)$. Mp 201-203 ${ }^{\circ} \mathrm{C} .{ }^{1} \mathrm{H}$ NMR $(300$ MHz, DMSO- $d 6): \delta 8.56-8.46$ (m, 2H, ArH), 7.95 (br, 1H, CONH), $7.87(\mathrm{t}, J=7.47 \mathrm{~Hz}, 1 \mathrm{H}, \mathrm{ArH}), 7.78$ (d, $J=8.16 \mathrm{~Hz}, 1 \mathrm{H}, \mathrm{ArH}), 7.63-$ $7.58(\mathrm{~m}, 3 \mathrm{H}, \mathrm{ArH}$ and $\mathrm{NH}), 7.45(\mathrm{~d}, J=15.78 \mathrm{~Hz}, 1 \mathrm{H}, \mathrm{COCH}=\mathrm{CH})$, $7.28(\mathrm{~d}, J=8.37 \mathrm{~Hz}, 1 \mathrm{H}, \mathrm{ArH}), 6.55(\mathrm{~d}, J=15.78 \mathrm{~Hz}, 1 \mathrm{H}, \mathrm{COC} \underline{\mathrm{H}}=$ $\mathrm{CH}), 4.02$ (d, J=4.74 Hz, 2H, NHC $\underline{\mathrm{H}_{2}}$ ), 3.83 (s, 3H, $\left.\mathrm{OCH}_{3}\right), 3.58$ (br, 2H, C $\left.\underline{\mathrm{H}_{2}} \mathrm{NHCO}\right), 2.95$ (br, 2H, C4- $\mathrm{H}_{2}$ ), 2.68 (br, 2H, C1- $\mathrm{H}_{2}$ ), 1.83 (br, $4 \overline{\mathrm{H}, \mathrm{C} 2}-\underline{\mathrm{H}_{2}}$ and $\left.\mathrm{C} 3-\mathrm{H}_{2}\right) .{ }^{13} \mathrm{C} \mathrm{NMR}$ (125 MHz, DMSO-d6): $\delta 166.82,156.64,153.85,151.98,138.79,133.31,133.14,129.36$, $125.80,125.59,122.36,122.13,119.53,115.97,111.91,56.05$, 54.06, 48.69, 42.31, 36.93, 28.41, 24.20, 21.89, 20.79, 18.55, 17.19, 12.98. HRMS (ESI): calcd for $\mathrm{C}_{26} \mathrm{H}_{27} \mathrm{~N}_{3} \mathrm{O}_{4}[\mathrm{M}+\mathrm{H}]^{+}$446.2074, found 446.2077. HPLC (70\% methanol in water with $0.5 \%$ $\left.\mathrm{H}_{3} \mathrm{PO}_{4}\right): t_{\mathrm{R}}=3.06 \mathrm{~min}, 95.785 \%$.

(E)-3-(2-(Benzyloxy)phenyl)-N-(2-((1,2,3,4-tetrahydroacridin-9-yl)amino)ethyl)acrylamide (33). According to the procedure used to synthesize 8, 33 was synthesized from 7-33 (0.21 g, $0.83 \mathrm{mmol})$ to give a white powder $0.19 \mathrm{~g}(48.00 \%)$. Mp $116-118{ }^{\circ} \mathrm{C} .{ }^{1} \mathrm{H}$ NMR (300 MHz, DMSO-d6): $\delta 8.48$ (br, 2H, ArH), 7.95 (br, 1H, CONH), 7.88-7.75 (m, 3H, ArH), 7.57-7.51 (m, 2H, ArH), 7.46-7.32 (m, 6H, $\mathrm{ArH}$ and $\mathrm{NH}$ and $\mathrm{COCH}=\mathrm{CH}), 7.14(\mathrm{~d}, J=8.25 \mathrm{~Hz}, 1 \mathrm{H}, \operatorname{ArH})$, $6.98(\mathrm{t}, J=7.41 \mathrm{~Hz}, 1 \mathrm{H}, \mathrm{ArH}), 6.58(\mathrm{~d}, J=15.87 \mathrm{~Hz}, 1 \mathrm{H}, \mathrm{COC} \underline{\mathrm{H}}=$ $\mathrm{CH}), 5.21\left(\mathrm{~s}, 2 \mathrm{H}, \mathrm{OCH}_{2}\right), 4.02\left(\mathrm{~d}, J=4.92 \mathrm{~Hz}, 2 \mathrm{H}, \mathrm{NHC} \mathrm{H}_{2}\right), 3.56$ (d, $\left.J=5.22 \mathrm{~Hz}, 2 \mathrm{H}, \mathrm{C} \mathrm{H}_{2} \mathrm{NHCO}\right), 2.94$ (br, 2H, C4- $\left.\mathrm{H}_{2}\right), 2.66$ (br, $2 \mathrm{H}, \mathrm{C} 1-\underline{\mathrm{H}}_{2}$ ), $1.80\left(\mathrm{br}, \overline{4 \mathrm{H}}, \mathrm{C} 2-\mathrm{H}_{2}\right.$ and $\left.\mathrm{C} 3-\mathrm{H}_{2}\right) .{ }^{13} \mathrm{C}$ NMR (125 MHz, DMSO- $d 6): \delta 167.28,156.92,156.61,150.94,138.33,137.35$, $134.71,133.29,131.53,129.00,128.41,128.00,127.88,125.80$, $125.55,123.86,121.93,121.48,119.52,115.94,113.64,111.88$, 70.01, 48.91, 28.39, 24.17, 21.87, 20.77. HRMS (ESI): calcd for $\mathrm{C}_{31} \mathrm{H}_{31} \mathrm{~N}_{3} \mathrm{O}_{2}[\mathrm{M}+\mathrm{H}]^{+}$478.2489, found 478.2476. HPLC (70\% methanol in water with $\left.0.5 \% \mathrm{H}_{3} \mathrm{PO}_{4}\right): t_{\mathrm{R}}=7.96 \mathrm{~min}, 95.046 \%$.

(E)-3-(3-(Benzyloxy)phenyl)-N-(2-((1,2,3,4-tetrahydroacridin-9-yl)amino)ethyl)acrylamide (34). According to the procedure used to synthesize 8, 34 was synthesized from $7-34(0.21 \mathrm{~g}, 0.83 \mathrm{mmol})$ to give a white powder $0.18 \mathrm{~g}$ (45.48\%). Mp 112-115 ${ }^{\circ} \mathrm{C} .{ }^{1} \mathrm{H}$ NMR (300 MHz, DMSO-d6): $\delta 8.49$ (br, 2H, ArH), 7.97 (br, 1H, CONH), $7.89(\mathrm{t}, J=7.59 \mathrm{~Hz}, 1 \mathrm{H}, \mathrm{ArH}), 7.79$ (d, $J=7.95 \mathrm{~Hz}, 1 \mathrm{H}, \mathrm{ArH}), 7.58$ $(\mathrm{t}, J=7.05 \mathrm{~Hz}, 1 \mathrm{H}, \mathrm{ArH}), 7.46-7.32(\mathrm{~m}, 7 \mathrm{H}, \mathrm{ArH}$ and $\mathrm{COCH}=\mathrm{CH})$, 7.20 (br, 1H, NH), 7.14 (d, $J=7.53 \mathrm{~Hz}, 1 \mathrm{H}, \mathrm{ArH}), 7.03$ (d, $J=$ $6.57 \mathrm{~Hz}, 1 \mathrm{H}, \mathrm{ArH}), 6.57(\mathrm{~d}, J=15.87 \mathrm{~Hz}, 1 \mathrm{H}, \mathrm{COC} \underline{\mathrm{H}}=\mathrm{CH}), 5.13(\mathrm{~s}$, $\left.2 \mathrm{H}, \mathrm{OCH}_{2} \mathrm{Ar}\right), 4.02\left(\mathrm{~d}, J=6.81 \mathrm{~Hz}, 2 \mathrm{H}, \mathrm{NHC}_{2}\right.$ ), 3.57 (d, $J=$ $5.25 \mathrm{~Hz}, 2 \mathrm{H}, \mathrm{C}_{2} \mathrm{NHCO}$ ), 2.95 (br, 2H, C4- $\underline{\mathrm{H}}_{2}$ ), 2.68 (br, 2H, C1$\underline{\mathrm{H}_{2}}$ ), 1.83 (br, $\overline{4 \mathrm{H}}, \mathrm{C} 2-\underline{\mathrm{H}_{2}}$ and $\left.\mathrm{C} 3-\underline{\mathrm{H}_{2}}\right) .{ }^{13} \mathrm{C}$ NMR $(125 \mathrm{MHz}$, DMSO-d6): $\delta 166.74,159.13,155.58,152.06,139.50,137.37$, 136.66, 132.36, 130.51, 128.93, 128.36, 128.24, 125.42, 125.27, 122.46, 120.87, 120.53, 116.61, 114.23, 112.43, 69.67, 48.43, 29.18, 24.51, 22.13, 21.05. HRMS (ESI): calcd for $\mathrm{C}_{31} \mathrm{H}_{31} \mathrm{~N}_{3} \mathrm{O}_{2}[\mathrm{M}+\mathrm{H}]^{+}$ 478.2489, found 478.2483. HPLC (70\% methanol in water with $\left.0.5 \% \mathrm{H}_{3} \mathrm{PO}_{4}\right): t_{\mathrm{R}}=8.69 \min , 96.547 \%$.

(E)-3-(4-(Benzyloxy)phenyl)-N-(2-((1,2,3,4-tetrahydroacridin-9-yl)amino)ethyl)acrylamide (35). According to the procedure used to synthesize 8, 35 was synthesized from 7-35 (0.21 g, $0.83 \mathrm{mmol})$ to give a white powder $0.21 \mathrm{~g}$ (53.06\%). Mp 120-122 ${ }^{\circ} \mathrm{C} .{ }^{1} \mathrm{H}$ NMR (300 MHz, DMSO-d6): $\delta 8.49$ (br, 2H, ArH), 7.99 (br, 1H, CONH), $7.86(\mathrm{t}, J=7.58 \mathrm{~Hz}, 1 \mathrm{H}, \mathrm{ArH}), 7.78$ (d, $J=7.74 \mathrm{~Hz}, 1 \mathrm{H}, \mathrm{ArH}), 7.59-$ $7.32(\mathrm{~m}, 9 \mathrm{H}, \mathrm{ArH}$ and $\mathrm{COCH}=\mathrm{CH}$ and $\mathrm{NH}), 7.04(\mathrm{~d}, J=8.71 \mathrm{~Hz}$, $2 \mathrm{H}, \operatorname{ArH}), 6.43(\mathrm{~d}, J=15.78 \mathrm{~Hz}, 1 \mathrm{H}, \mathrm{COCH}=\mathrm{CH}), 5.13(\mathrm{~s}, 2 \mathrm{H}$, $\mathrm{OCH}_{2} \mathrm{Ar}$ ), 4.01 (d, $J=5.01 \mathrm{~Hz}, 2 \mathrm{H}, \mathrm{NHC} \mathrm{H}_{2}$ ), 3.55 (d, $J=5.37 \mathrm{~Hz}$, 2H, $\mathrm{C} \mathrm{H}_{2} \mathrm{NHCO}$ ), 2.94 (br, 2H, C4- $\mathrm{H}_{2}$ ), 2.68 (br, 2H, C1- $\mathrm{H}_{2}$ ), 1.82 (br, 4H, C2- $\mathrm{H}_{2}$ and $\mathrm{C} 3-\underline{\mathrm{H}_{2}}$ ). ${ }^{13} \mathrm{C} \mathrm{NMR} \mathrm{(75} \mathrm{MHz,} \mathrm{CDCl}_{3}$ ): $\delta 167.39,159.64,157.91,150.29,146.63,140.48,135.98,128.91$, $128.15,127.92$, 127.64, 127.11, 126.96, 123.24, 122.28, 119.47, 117.61, 115.52, 114.64, 69.55, 49.43, 40.15, 33.29, 24.58, 22.51, 22.15. HRMS (ESI): calcd for $\mathrm{C}_{31} \mathrm{H}_{31} \mathrm{~N}_{3} \mathrm{O}_{2}[\mathrm{M}+\mathrm{H}]^{+} 478.2489$, found 478.2488. HPLC (70\% methanol in water with $0.5 \%$ $\left.\mathrm{H}_{3} \mathrm{PO}_{4}\right): t_{\mathrm{R}}=8.40 \mathrm{~min}, 96.871 \%$.

(E)-3-(4-(Benzyloxy)-3-methoxyphenyl)-N-(2-((1,2,3,4-tetrahydroacridin-9-yl)amino)ethyl)acrylamide (36). According to the procedure used to synthesize 8, 36 was synthesized from 7-36 (0.24 g, $0.83 \mathrm{mmol}$ ) to give a white powder $0.25 \mathrm{~g}$ (59.43\%). Mp 109$111^{\circ} \mathrm{C} .{ }^{1} \mathrm{H}$ NMR $\left(300 \mathrm{MHz}, \mathrm{CDCl}_{3}\right): \delta 7.99-7.90(\mathrm{~m}, 2 \mathrm{H}, \mathrm{ArH}), 7.59$ $(\mathrm{d}, J=15.57 \mathrm{~Hz}, 1 \mathrm{H}, \mathrm{COCH}=\mathrm{CH}), 7.50-7.29(\mathrm{~m}, 7 \mathrm{H}, \mathrm{ArH}), 7.04-$ $7.01(\mathrm{~m}, 2 \mathrm{H}, \mathrm{ArH}$ and NH), $6.86(\mathrm{~d}, J=8.04 \mathrm{~Hz}, 1 \mathrm{H}, \mathrm{ArH}), 6.61(\mathrm{br}$, $1 \mathrm{H}, \mathrm{CONH}), 6.35(\mathrm{~d}, J=15.60 \mathrm{~Hz}, 1 \mathrm{H}, \mathrm{COC} \underline{\mathrm{H}}=\mathrm{CH}), 5.18(\mathrm{~s}, 2 \mathrm{H}$, $\mathrm{OCH}_{2} \mathrm{Ar}$ ), $3.90\left(\mathrm{~s}, 3 \mathrm{H}, \mathrm{OCH}_{3}\right), 3.76-3.71\left(\mathrm{~m}, 4 \mathrm{H}, \mathrm{NHC} \mathrm{H}_{2}\right.$ and $\mathrm{C} \mathrm{H}_{2} \mathrm{NHCO}$ ), 3.02 (br, 2H, C4- $\mathrm{H}_{2}$ ), 2.66 (br, 2H, C1- $\overline{\mathrm{H}_{2}}$ ), 1.85 (br, $4 \mathrm{H}, \mathrm{C} 2-\mathrm{H}_{2}$ and $\left.\mathrm{C} 3-\mathrm{H}_{2}\right) \cdot{ }^{13} \mathrm{C} \mathrm{NMR}\left(75 \mathrm{MHz} \mathrm{CDCl}_{3}\right): \delta 167.50$, $156.41,151.86,149.32, \overline{149} .18,140.60,136.09,128.42,128.11$, $127.61,127.52,126.77,126.16,123.31,122.55,121.24,118.61$, 118.04, 114.53, 113.05, 110.04, 70.37, 55.46, 49.52, 39.99, 31.02, 24.36, 22.31, 21.77. HRMS (ESI): calcd for $\mathrm{C}_{32} \mathrm{H}_{34} \mathrm{~N}_{3} \mathrm{O}_{3}[\mathrm{M}+\mathrm{H}]^{+}$ 508.2595, found 508.2591. HPLC (70\% methanol in water with $\left.0.5 \% \mathrm{H}_{3} \mathrm{PO}_{4}\right): t_{\mathrm{R}}=5.97 \mathrm{~min}, 96.738 \%$.

(E)-3-(2-Aminophenyl)-N-(2-((1,2,3,4-tetrahydroacridin-9-yl)amino)ethyl)acrylamide (37). 27 (0.2 g, $0.48 \mathrm{mmol})$ and stannous chloride dehydrate $(0.54 \mathrm{~g}, 2.40 \mathrm{mmol})$ were dissolved in $10 \mathrm{~mL} \mathrm{EtOH}$, the mixture was stirred at $80{ }^{\circ} \mathrm{C}$ for $6 \mathrm{~h}$. Then the reaction cooled to room temperature and acidized by $\mathrm{AcOH}$. The reaction was filtered and the concentrated the filtrate. Then the filtrate was purified by column chromatography $\left(\mathrm{CH}_{2} \mathrm{Cl}_{2} / \mathrm{MeOH}=40: 1\right.$, v/v, with $0.1 \%$ 
triethylamine) to give an orange powder $0.07 \mathrm{~g}$ (37.63\%). Mp 205$206{ }^{\circ} \mathrm{C} .{ }^{1} \mathrm{H}$ NMR (300 MHz, DMSO- $\left.d 6\right): \delta 8.81$ (br, $\left.1 \mathrm{H}, \mathrm{ArH}\right), 8.55$ (d, $J=7.71 \mathrm{~Hz}, 1 \mathrm{H}, \mathrm{ArH}), 8.05$ (br, 2H, CONH and $\mathrm{ArH}), 7.83$ (br, $1 \mathrm{H}$, $\mathrm{ArH}), 7.69$ (d, $J=15.54 \mathrm{~Hz}, 1 \mathrm{H}, \mathrm{COCH}=\mathrm{CH}$ ), 7.55 (br, $1 \mathrm{H}, \mathrm{ArH})$, 7.26 (d, $J=7.50 \mathrm{~Hz}, 1 \mathrm{H}, \operatorname{ArH}), 7.02(\mathrm{br}, 1 \mathrm{H}, \mathrm{NH}), 6.68$ (d, $J=$ $7.71 \mathrm{~Hz}, 1 \mathrm{H}, \mathrm{ArH}), 6.53$ (br, $1 \mathrm{H}, \mathrm{ArH}), 6.40$ (d, $J=15.57 \mathrm{~Hz}, 1 \mathrm{H}$, $\mathrm{COC} \underline{\mathrm{H}}=\mathrm{CH}), 5.42\left(\mathrm{br}, 2 \mathrm{H}, \mathrm{NH}_{2}\right), 4.02\left(\mathrm{br}, 2 \mathrm{H}, \mathrm{NHC}_{2}\right), 3.54(\mathrm{br}$, $\left.2 \mathrm{H}, \mathrm{C} \mathrm{H}_{2} \mathrm{NHCO}\right), 2.73$ (br, 2H, C1- $\mathrm{H}_{2}$ ), 1.82 (br, 4H, C2- $\mathrm{H}_{2}$ and C3- $\underline{\mathrm{H}_{2}}$ ). ${ }^{13} \mathrm{C}$ NMR (125 MHz, DMSO- $\left.d 6\right): \delta 166.11,156.23,151.50$, 148.09 , 141.72, 137.47, 132.98, 130.80, 129.15, 126.14, 125.61, 125.49, 124.62, 123.39, 123.24, 116.30, 112.25, 48.41, 28.78, 24.32, 21.98, 20.92, 20.80. HRMS (ESI): calcd for $\mathrm{C}_{24} \mathrm{H}_{26} \mathrm{~N}_{4} \mathrm{O}_{2}[\mathrm{M}+\mathrm{H}]^{+}$ 387.2179 , found 387.2186 . HPLC $(70 \%$ methanol in water with $\left.0.5 \% \mathrm{H}_{3} \mathrm{PO}_{4}\right): t_{\mathrm{R}}=4.42 \mathrm{~min}, 96.101 \%$.

(E)-3-(3-Aminophenyl)-N-(2-((1,2,3,4-tetrahydroacridin-9-yl)amino)ethyl)acrylamide (38). According to the procedure used to synthesize 37,38 was synthesized from $28(0.2 \mathrm{~g}, 0.48 \mathrm{mmol})$ to give an orange powder $0.06 \mathrm{~g}(32.26 \%)$. Mp 207-209 ${ }^{\circ} \mathrm{C} .{ }^{1} \mathrm{H}$ NMR (300 MHz, DMSO- $d 6$ ): $\delta 8.78$ (br, $1 \mathrm{H}, \mathrm{ArH}), 8.58$ (d, $J=7.60 \mathrm{~Hz}$, 1H, ArH), 8.10 (br, 2H, CONH and ArH), 7.78 (br, 1H, ArH), 7.70 $(\mathrm{d}, J=15.90 \mathrm{~Hz}, 1 \mathrm{H}, \mathrm{COCH}=\mathrm{CH}), 7.59(\mathrm{br}, 1 \mathrm{H}, \mathrm{ArH}), 7.22(\mathrm{~d}, J=$ $7.66 \mathrm{~Hz}, 1 \mathrm{H}, \mathrm{ArH}), 7.03$ (br, 1H, NH), 6.66 (d, $J=7.80 \mathrm{~Hz}, 1 \mathrm{H}$, $\mathrm{ArH}), 6.49$ (br, 1H, ArH), $6.38(\mathrm{~d}, J=15.88 \mathrm{~Hz}, 1 \mathrm{H}, \mathrm{COCH}=\mathrm{CH})$, 5.37 (br, 2H, $\mathrm{NH}_{2}$ ), $4.00\left(\mathrm{br}, 2 \mathrm{H}, \mathrm{NHC} \mathrm{H}_{2}\right.$ ), 3.59 (br, 2H, $\mathrm{C} \mathrm{H}_{2}$ NHCO), 2.70 (br, 2H, C1- $\mathrm{H}_{2}$ ), 1.81 (br, 4H, C2- $\mathrm{H}_{2}$ and C3$\left.\underline{\mathrm{H}_{2}}\right) .{ }^{13} \mathrm{C}$ NMR (125 MHz, DMSO-d6): 167.68, 162.35, 148.16, 140.69, 135.83, 132.91, 130.78, 128.33, 127.04, 125.76, 125.49, $124.39,122.36,122.19,116.62,111.75,48.39,28.39,24.44$, 21.98, 21.82, 20.74, 20.56. HRMS (ESI): calcd for $\mathrm{C}_{24} \mathrm{H}_{26} \mathrm{~N}_{4} \mathrm{O}_{2}[\mathrm{M}$ $+\mathrm{H}]^{+} 387.2179$, found 387.2183 . HPLC $(70 \%$ methanol in water with $\left.0.5 \% \mathrm{H}_{3} \mathrm{PO}_{4}\right): t_{\mathrm{R}}=4.69 \mathrm{~min}, 98.131 \%$.

(E)-3-(4-Aminophenyl)-N-(2-((1,2,3,4-tetrahydroacridin-9-yl)amino)ethyl)acrylamide (39). According to the procedure used to synthesize 37, 39 was synthesized from $29(0.2 \mathrm{~g}, 0.48 \mathrm{mmol})$ to give an orange powder $0.07 \mathrm{~g}$ (37.63\%). Mp 208-209 ${ }^{\circ} \mathrm{C} .{ }^{1} \mathrm{H}$ NMR (300 MHz, DMSO-d6): $\delta 8.46$ (d, $J=8.61 \mathrm{~Hz}, 1 \mathrm{H}, \mathrm{ArH}), 8.38$ (br, $1 \mathrm{H}$, ArH), 7.87-7.79 (m, 4H, CONH and ArH and $\mathrm{NH}), 7.54(\mathrm{t}, J=$ $6.68 \mathrm{~Hz}, 1 \mathrm{H}, \mathrm{ArH}), 7.30-7.20(\mathrm{~m}, 3 \mathrm{H}, \mathrm{COCH}=\mathrm{CH}$ and $\mathrm{ArH}), 6.54(\mathrm{~d}$, $J=8.28 \mathrm{~Hz}, 2 \mathrm{H}, \mathrm{ArH}), 6.24(\mathrm{~d}, J=15.66 \mathrm{~Hz}, 1 \mathrm{H}, \mathrm{COC} \underline{\mathrm{H}}=\mathrm{CH}), 5.61$ (br, $2 \mathrm{H}, \mathrm{NH}_{2}$ ), 3.97 (d, $J=4.32 \mathrm{~Hz}, 2 \mathrm{H}, \mathrm{NHC} \mathrm{H}_{2}$ ), 3.52 (d, $J=$ $5.16 \mathrm{~Hz}, 2 \mathrm{H}, \mathrm{C} \mathrm{H}_{2} \mathrm{NHCO}$ ), 2.95 (br, $2 \mathrm{H}, \mathrm{C} 4-\mathrm{H}_{2}$ ), 2.68 (br, 2H, C1$\left.\underline{\mathrm{H}}_{2}\right), 1.81$ (br, $4 \overline{\mathrm{H},} \mathrm{C} 2-\mathrm{H}_{2}$ and $\left.\mathrm{C} 3-\mathrm{H}_{2}\right) .{ }^{13} \mathrm{C} \mathrm{NMR}(125 \mathrm{MHz}, \mathrm{DMSO}-$ $\overline{d 6)}: \delta 166.12,156.27,148.09,145.91,141.72,137.48,133.03,130.80$, $129.15,126.13,125.64,125.51,124.62,123.25,120.10,116.27$, 112.21, 48.41, 28.74, 24.32, 21.97, 20.91, 20.79. HRMS (ESI): calcd for $\mathrm{C}_{24} \mathrm{H}_{26} \mathrm{~N}_{4} \mathrm{O}_{2}[\mathrm{M}+\mathrm{H}]^{+} 387.2179$, found 387.2175. HPLC (70\% methanol in water with $\left.0.5 \% \mathrm{H}_{3} \mathrm{PO}_{4}\right): t_{\mathrm{R}}=4.33 \mathrm{~min}, 97.356 \%$.

\section{In vitro inhibitory evaluations on $\mathrm{AChE}$ and $\mathrm{BuChE}$}

The investigation of the inhibitory effects of the test compounds was performed followed the method of Ellman et al., using a Shimadzu 160 spectrophotometer. AChE (EC 3.1.1.7, Type VI-S, from Electric Eel, C3389; from human, C1682) and BuChE (EC 3.1.1.8, from equine serum, C0663; from human, B4186), 5,5'-dithiobis(2nitrobenzoic acid) (DTNB, D218200), acetylthiocholine iodide (ATC, A5751), and butyrylthiocholine iodide (BTC, B3253) were purchased from Sigma-Aldrich (St. Louis, MO, USA). AChE/BuChE stock solution was diluted before use to give 2.5 units per $\mathrm{mL}$ (for eeAChE, eqBuChE and huAChE) or 0.5 units per $\mathrm{mL}$ for huBuChE. ATC/BTC iodide solution (0.075 M) was prepared in deionized water. DTNB solution $(0.01 \mathrm{M})$ was prepared in water containing $0.15 \%(\mathrm{w} / \mathrm{v})$ sodium bicarbonate. For buffer preparation, potassium dihydrogen phosphate $(1.36 \mathrm{~g}, 10 \mathrm{mmol})$ was dissolved in $100 \mathrm{~mL}$ of water. The $\mathrm{pH}$ of the solution was adjusted to $8.0 \pm 0.1$ by $\mathrm{KOH}$. Stock solutions of the test compounds were dissolved in ethanol to give a final concentration of $10^{-4} \mathrm{M}$ when diluted to the final volume of $3.32 \mathrm{~mL}$. For each compound, a dilution series of at least five different concentrations (normally $10^{-5}$ to $10^{-9} \mathrm{M}$ ) were prepared.

For measurement, a cuvette containing $3.0 \mathrm{~mL}$ of phosphate buffer, $100 \mu \mathrm{L}$ of AChE or BuChE, $100 \mu \mathrm{L}$ of DTNB and $100 \mu \mathrm{L}$ of the test compound solution were added. After the addition of 20 $\mu \mathrm{L}$ of ATC or BTC, the reaction was initiated and solution was mixed immediately. Two minutes (eeAChE and eqBuChE) or fifteen minutes (huAChE and huBuChE) after substrate addition, the absorption was determined at $25{ }^{\circ} \mathrm{C}$ (eeAChE and eqBuChE) or $37{ }^{\circ} \mathrm{C}$ (huAChE and huBuChE) at $412 \mathrm{~nm}$. For the reference value, $100 \mu \mathrm{L}$ of water replaced the test compound solution. For determining the blank value, additionally $100 \mu \mathrm{L}$ of water replaced the enzyme solution. The measurement for each concentration was performed in triplicate. The inhibition curve was fitted by plotting percentage enzyme activity (100\% for the reference) versus logarithm of test compound concentration. The $\mathrm{IC}_{50}$ values were calculated by GraphPad Prism 5 and the data were shown in mean \pm SEM.

\section{Kinetic studies of AChE inhibition}

Kinetic studies were performed in the same manner to the determination of ChEs inhibition, while the substrate (ATC/BTC) was used in concentrations of $25,50,90,150,226$, and $452 \mu \mathrm{M}$. The concentrations of test compounds were set to $0,20,60,100$, $200 \mathrm{nM}$ for 36. The enzymatic reaction was extended to $4 \mathrm{~min}$ (eeAChE and eqBuChE) or $20 \mathrm{~min}$ (huAChE and huBuChE) before the determination of the absorption. $V_{\max }$ and $K_{\mathrm{m}}$ values of the Michaelis-Menten kinetics were calculated by nonlinear regression from substrate-velocity curves using GraphPad Prism 5. Linear regression was used for fitting the Lineweaver-Burk plots.

\section{Molecular modeling studies}

The docking study was performed by CDOCKER module implemented in Discovery Studio (version 3.0, BIOVIA, USA). CDOCKER is a grid-based molecular docking method that employs CHARMm. ${ }^{46}$ Random ligand conformations are generated from the initial ligand structure through high temperature molecular dynamics, followed by random rotations. The random conformations are refined by grid-based simulated annealing and a final grid-based or full forcefield minimization. The solutions are then clustered according to position and conformation and ranked by energy.

The co-crystal structure of huAChE bound with donepezil was selected for molecular docking. The structure was download from Protein Data Bank (PDB, ID: 4EY7). It was prepared by 
"Prepare Protein" module in DS for further docking. Missed sidechains were added and the water molecules were removed, then it was protonated at $\mathrm{pH}$ 7.4. For the test compounds docked into huAChE, they were first sketched in DS, and then prepared by using "Prepare Ligands" module to protonate at $\mathrm{pH}$ 7.4. The resulted molecules were minimized by "Minimize Ligands" module. The "Smart Minimizer" algorithm was used to perform the minimization, with max steps set to 2000, RMS Gradient set to 0.01 . Other parameters were set as default. ${ }^{47}$

A sphere (in $10 \AA$ A radius) around donepezil was determined as the binding site, including both CAS and PAS of huAChE. For the simulated annealing, heating steps and cooling steps was set to 2000 and 5000, respectively, while heating and cooling temperature was set to 700 , and 310 , respectively. Other parameters were kept as default. After docking, ten top-ranked conformations were retained for analysis. Binding patterns of the docked molecules were described by DS visualizer. ${ }^{48}$

\section{Inhibition of self-induced $A \beta_{1-42}$ aggregation}

Inhibition of self-induced $\mathrm{A} \beta_{1-42}$ aggregation was measured using a Thioflavin T (ThT)-(T3516, Sigma-Aldrich, St. Louis, MO, USA) binding assay as previously described. ${ }^{49}$ Aliquots of $2.0 \mu \mathrm{L}$ of $\mathrm{A} \beta_{1-42}$ (AS-64129-05 Anaspec Inc.), lyophilized from $2 \mathrm{mg}$ $\mathrm{mL}^{-1}$ HFIP (1,1,1,3,3,3-hexafluoro-2-propanol, 52517, SigmaAldrich, St. Louis, MO, USA) and dissolved in DMSO, were incubated for $24 \mathrm{~h}$ at room temperature in $0.215 \mathrm{M}$ sodium phosphate buffer ( $\mathrm{pH} 8.0$ ) at a final concentration of $500 \mu \mathrm{M}$. Test compounds were dissolved in DMSO and then diluted by buffer to a final concentration of $20 \mu \mathrm{M}$. After incubation, the samples were diluted to a final volume of $150 \mu \mathrm{L}$ with $50 \mathrm{mM}$ glycine- $\mathrm{NaOH}$ buffer ( $\mathrm{pH}$ 8.5) containing $5 \mathrm{mM}$ thioflavin $\mathrm{T}$. Fluorescence signal was determined (excitation wavelength $450 \mathrm{~nm}$, emission wavelength $485 \mathrm{~nm}$ ) on a SpectraMax Paradigm Multimode Reader (Molecular Device, USA).

The inhibitory rate of $\mathrm{A} \beta_{1-42}$ aggregation was calculated according to the following equation: $(1-\mathrm{IFi} / \mathrm{IFc}) \times 100 \%$. Here, IFi and IFc were the fluorescence intensities obtained for absorbance in the presence and absence of inhibitors, respectively, after subtracting the background fluorescence of the $5 \mathrm{mM}$ thioflavin $\mathrm{T}$ solution. Each measurement was measured in triplicate. The inhibitory rate of the test compound was shown in mean $\pm \mathrm{SD}$.

\section{Cyto-protection and cell toxicity against PC-12 neuroblastoma} cells

Cytotoxicity was determined by using 3-(4,5-dimethylthiazol-2yl)-2,5-diphenyltetrazoliumbromide (MTT) assay. The PC-12 cell line was purchased from Cell Culture Center at the Institute of Basic Medical Sciences, Chinese Academy of Medical Sciences. MTT was purchased from Sigma (M2128, St. Louis, MO). It was dissolved in phosphate buffered saline (PBS) to a stock concentration of $5 \mathrm{mg} \mathrm{mL}{ }^{-1}$ and stored at $-20^{\circ} \mathrm{C}$. PC-12 cells were plated in 96-well plates, raised to a population of $1 \times$ $10^{4}$ cells per well, and incubated overnight. After cells were treated with density gradient of test compounds or DMSO for $24 \mathrm{~h}$ at $37^{\circ} \mathrm{C}$ or treated with $500 \mu \mathrm{M} \mathrm{H}_{2} \mathrm{O}_{2}$ for another $12 \mathrm{~h}, 20.0$ $\mu \mathrm{L}$ of MTT solution was added into each well of the plate and incubated for $4 \mathrm{~h}$. Then the solution was removed and $150.0 \mu \mathrm{L}$ of DMSO was added into each well to dissolve the MTTformazan crystals. DMSO was used as a negative control. The absorbance values (OD value) were read at $570 \mathrm{~nm}$ by Elx800 Absorbance Microplate Reader (BioTek, Vermont, USA). The inhibitory rate for each concentration of the test compound was calculated by the equation as follows:

$$
\mathrm{IR}=\left[1-\left(\mathrm{OD}_{\text {test }}-\mathrm{OD}_{\text {blank }}\right) /\left(\mathrm{OD}_{\text {control }}-\mathrm{OD}_{\text {blank }}\right)\right] \times 100 \% .
$$

Here, $\mathrm{OD}_{\text {test }}, \mathrm{OD}_{\text {blank }}$, and $\mathrm{OD}_{\text {control }}$ stand for the $\mathrm{OD}$ value from test compound, background, and DMSO, respectively. The $\mathrm{IC}_{50}$ values were calculated by GraphPad Prism 5 and the data were shown in mean \pm SEM.

\section{A statement identifying the institutional and/or licensing committee experimental approval}

All animal studies were performed in compliance with the Chinese Academy of Medical Sciences and the Animal Ethics Committees of the Institute of Materia Medica. The animal experiments were performed in accordance with the National Institutes of Health Guide for the Care and Use of Laboratory Animals with the approval of the Center for New Drug Evaluation and Research of China Pharmaceutical University (Nanjing, China).

\section{Behavioral studies}

Behavioral studies were performed by using adult male ICR mice (8-10 weeks old, weight 20-25 g), which were purchased from the Yangzhou University Medical Center (Yangzhou, China). Scopolamine hydrobromide was supplied by Aladdin Reagents (H1507073, Shanghai, China). Tacrine was synthesized in our lab with $>95 \%$ purity as determined by HPLC.

The mice were separated into five groups as follows: (i) vehicle as blank control, (ii) scopolamine as model group, (iii) tacrine plus scopolamine as positive control, (iv) compound 36 plus scopolamine as test group, and (v) compound $\mathbf{3 5}$ plus scopolamine as test group. Tacrine, 36 and $35\left(20 \mu \mathrm{mol} \mathrm{kg} \mathrm{kg}^{-1}\right.$ body weight) were orally administered to mice in groups (iii), (iv), and (v), respectively, $30 \mathrm{~min}$ before the ip administration of scopolamine $\left(1 \mathrm{mg} \mathrm{kg}^{-1}\right)$ or saline for 10 consecutive days.

Cognitive function was evaluated by the Morris water maze analysis-management system (Panlab SMART 3.0, America), according to the method previously described..$^{37}$ The maze was placed in a lit room with visual cues at $25^{\circ} \mathrm{C}$. An escape platform (10 cm diameter) was located in the center of one quadrant of the circular pool (120 cm diameter, $60 \mathrm{~cm}$ height) with a depth of $40 \mathrm{~cm}$ water. The behavioral study of each mouse included 5 days of learning and memory training and a probe trial on day 6 . The animal starting positions faced to the pool wall, and were pseudorandomized for each trial. For the cognitive evaluation, each mouse was individually evaluated on both visible-platform (days 1-2) and hidden-platform (days 3-5) versions of the water maze. All mice received nonspatial pretraining during the first two training days, which prepared them for the subsequent spatial 
learning test. During the two days, mice were trained to find the platform that was labeled by a small flag ( $5 \mathrm{~cm}$ tall). The hiddenplatform version was used to determine the retention of memory to find the platform. During the hidden-platform training trials, the escape platform was placed $1 \mathrm{~cm}$ below the surface of the water. On each day, the animal was subjected to two trials, each of which lasted for $90 \mathrm{~s}$. The time for the mouse to find the platform (a successful escape) was recorded. If a mouse failed to reach the platform within $90 \mathrm{~s}$, the test was terminated and the animal was gently navigated to the platform by hand. Whether a mouse was successful or failed to reach the platform within $90 \mathrm{~s}$, it was kept on the platform for $30 \mathrm{~s}$. On the last day (day 6), the platform was removed from its location and the animals were given a probe trial in which they had $90 \mathrm{~s}$ to search for the platform. The time taken to reach the missing platform and the number of times the animals crossed the platform location were recorded.

Data for the time of escape latency, the trajectory traveled, and the number of platform location crossings were recorded by Panlab SMART 3.0 and processed by Graphpad Prism 5.

\section{Hepatotoxicity studies}

Hepatotoxicity was evaluated according to the method previously described ${ }^{32}$ by using adult male ICR mice (8-10 weeks old, weighing 20-25 g) obtained from the Yangzhou University Medicine Centre (Yangzhou, China). Tacrine and the test compounds were dissolved in a sodium carboxymethyl cellulose (CMC-Na) solution (0.5 g CMC-Na in $100 \mathrm{~mL}$ distilled water). Concentration of $3 \mathrm{mg} / 100 \mathrm{~g}$ body wt of tacrine, corresponding to $151.5 \mu \mathrm{mol} \mathrm{kg}{ }^{-1}$ body wt, was administered intragastrically (ig). Equimolar dose of test compounds to that of tacrine was administered ig. 8, 22, and $36 \mathrm{~h}$ after the administration, heparinized serum was collected from the retrobulbar plexus and subjected to hepatotoxicity evaluation. The activity of aspartate aminotransferase (AST) and alanine aminotransferase (ALT), two indicators of liver damage, was determined using corresponding assay kit (EF551 and EF550 for ALT, EH027 and EF548 for AST, Wako, Japan). The data were processed by Biochemical Analyzer (HITACHI 7020, Japan).

$1 \mathrm{~h}$ after the collection of retrobulbar blood, mice were sacrificed and livers were harvested for morphological studies by using immunohistochemical method. Two $3 \mathrm{~mm}$ sections of each liver extending from the hilus to the margin of the left lateral lobe were isolated by Ultra-Thin Semiautomatic Microtome (Leica RM2245, Germany) and immediately placed in 10\% buffered formaldehyde, fixed for two days, and embedded together in one paraffin block by using Paraffin Embedding Station (Leica EG1150H, Germany). Subsequently, $5 \mu \mathrm{m}$ sections were prepared from these paraffin blocks. They were deparaffinated and stained with hematoxylin and eosin or by means of the periodic acid-Schiff procedure for glycogen.

\section{Author contributions}

C. Y. wrote the result and discussion of main manuscript text. S. P. wrote the introduction part. L. Z. wrote the methods and materials of the manuscript. Z. J., G. K., L. Q., H. Y. and L. X. were responsible for the synthesis of the inhibitor. P. Q. was responsible for the characterization of the compounds. B. Y. and $\mathrm{W}$. L. were responsible for the biological determination. T. $\mathrm{X}$. revised the manuscript. All authors reviewed the manuscript.

\section{Conflict of interest}

The authors declare no competing financial interests.

\section{Acknowledgements}

We gratefully thank the support from the grants 81402851 and 81573281 of National Natural Science Foundation of China, BK20140957 of Natural Science Foundation of Jiangsu Province. We also thank the support from Fundamental Research Funds for the Central Universities (2015ZD009), Jiangsu Qing Lan Project, Top-notch Academic Programs Project of Jiangsu Higher Education Institutions (TAPP-PPZY2015A070) and Priority Academic Program Development of Jiangsu Higher Education Institutions (PAPD).

\section{References}

1 V. Tumiatti, A. Minarini, M. L. Bolognesi, A. Milelli, M. Rosini and C. Melchiorre, Curr. Med. Chem., 2010, 17, 1825-1838.

2 H. Tang, H. T. Zhao, S. M. Zhong, Z. Y. Wang, Z. F. Chen and H. Liang, Bioorg. Med. Chem. Lett., 2012, 22, 2257-2261.

3 D. J. Selkoe, Physiol. Rev., 2001, 81, 741-766.

4 J. Hardy, Neuron, 2006, 52, 3-13.

5 P. T. Francis, A. M. Palmer, M. Snape and G. K. Wilcock, J. Neurol., Neurosurg. Psychiatry, 1999, 66, 137-147.

6 E. Karran, M. Mercken and B. De Strooper, Nat. Rev. Drug Discovery, 2011, 10, 698-712.

7 C. Ballatore, V. M. Lee and J. Q. Trojanowski, Nat. Rev. Neurosci., 2007, 8, 663-672.

8 K. M. Webber, A. K. Raina, M. W. Marlatt, X. Zhu, M. I. Prat, L. Morelli, G. Casadesus, G. Perry and M. A. Smith, Mech. Ageing Dev., 2005, 126, 1019-1025.

9 L. Tapia-Arancibia, E. Aliaga, M. Silhol and S. Arancibia, Brain Res. Rev., 2008, 59, 201-220.

10 B. Su, X. Wang, A. Nunomura, P. I. Moreira, H. G. Lee, G. Perry, M. A. Smith and X. Zhu, Curr. Alzheimer Res., 2008, 5, 525-532.

11 K. J. Barnham, C. L. Masters and A. I. Bush, Nat. Rev. Drug Discovery, 2004, 3, 205-214.

12 K. Jomova and M. Valko, Toxicology, 2011, 283, 65-87.

13 L. Devi and H. K. Anandatheerthavarada, Biochim. Biophys. Acta, 2010, 1802, 11-19.

14 U. Holzgrabe, P. Kapkova, V. Alptuzun, J. Scheiber and E. Kugelmann, Expert Opin. Ther. Targets, 2007, 11, 161-179.

15 J. L. Sussman, M. Harel, F. Frolow, C. Oefner, A. Goldman, L. Toker and I. Silman, Science, 1991, 253, 872-879.

16 Y. Bourne, P. Taylor, Z. Radic and P. Marchot, EMBOJ., 2003, 22, 1-12. 
17 J. Cheung, M. J. Rudolph, F. Burshteyn, M. S. Cassidy, E. N. Gary, J. Love, M. C. Franklin and J. J. Height, J. Med. Chem., 2012, 55, 10282-10286.

18 M. Bartolini, C. Bertucci, V. Cavrini and V. Andrisano, Biochem. Pharmacol., 2003, 65, 407-416.

19 N. C. Inestrosa, J. P. Sagal and M. Colombres, Subcell. Biochem., 2005, 38, 299-317.

20 S. Darvesh, D. A. Hopkins and C. Geula, Nat. Rev. Neurosci., 2003, 4, 131-138.

21 C. Chianella, D. Gragnaniello, P. Maisano Delser, M. F. Visentini, E. Sette, M. R. Tola, G. Barbujani and S. Fuselli, Eur. J. Clin. Pharmacol., 2011, 67, 1147-1157.

22 A. V. Terry Jr and J. J. Buccafusco, J. Pharmacol. Exp. Ther., 2003, 306, 821-827.

23 M. Bajda, N. Guzior, M. Ignasik and B. Malawska, Curr. Med. Chem., 2011, 18, 4949-4975.

24 S. Leone, A. Ottani and A. Bertolini, Curr. Top. Med. Chem., 2007, 7, 265-275.

25 A. Minarini, A. Milelli, E. Simoni, M. Rosini, M. L. Bolognesi, C. Marchetti and V. Tumiatti, Curr. Top. Med. Chem., 2013, 13, 1771-1786.

26 R. A. de Aquino, L. V. Modolo, R. B. Alves and A. de Fatima, Curr. Drug Targets, 2013, 14, 378-397.

27 M. Benchekroun, M. Bartolini, J. Egea, A. Romero, E. Soriano, M. Pudlo, V. Luzet, V. Andrisano, M. L. Jimeno, M. G. Lopez, S. Wehle, T. Gharbi, B. Refouvelet, L. de Andres, C. Herrera-Arozamena, B. Monti, M. L. Bolognesi, M. I. Rodriguez-Franco, M. Decker, J. Marco-Contelles and L. Ismaili, ChemMedChem, 2015, 10, 523-539.

28 M. A. Ceschi, J. S. da Costa, J. P. Lopes, V. S. Camara, L. F. Campo, A. C. Borges, C. A. Goncalves, D. F. de Souza, E. L. Konrath, A. L. Karl, I. A. Guedes and L. E. Dardenne, Eur. J. Med. Chem., 2016, 121, 758-772.

29 M. Digiacomo, Z. Chen, S. Wang, A. Lapucci, M. Macchia, X. Yang, J. Chu, Y. Han, R. Pi and S. Rapposelli, Bioorg. Med. Chem. Lett., 2015, 25, 807-810.

30 R. S. Keri, C. Quintanova, S. M. Marques, A. R. Esteves, S. M. Cardoso and M. A. Santos, Bioorg. Med. Chem., 2013, 21, 4559-4569.

31 J. S. Lan, S. S. Xie, S. Y. Li, L. F. Pan, X. B. Wang and L. Y. Kong, Bioorg. Med. Chem., 2014, 22, 6089-6104.

32 S. Y. Li, N. Jiang, S. S. Xie, K. D. Wang, X. B. Wang and L. Y. Kong, Org. Biomol. Chem., 2014, 12, 801-814.
33 S. Liao, H. Deng, S. Huang, J. Yang, S. Wang, B. Yin, T. Zheng, D. Zhang, J. Liu, G. Gao, J. Ma and Z. Deng, Bioorg. Med. Chem. Lett., 2015, 25, 1541-1545.

34 J. Misik, J. Korabecny, E. Nepovimova, A. Kracmarova and J. Kassa, Neurosci. Lett., 2016, 612, 261-268.

35 E. Nepovimova, J. Korabecny, R. Dolezal, K. Babkova, A. Ondrejicek, D. Jun, V. Sepsova, A. Horova, M. Hrabinova, O. Soukup, N. Bukum, P. Jost, L. Muckova, J. Kassa, D. Malinak, M. Andrs and K. Kuca, J. Med. Chem., 2015, 58, 8985-9003.

36 B. N. Saglik, S. Ilgin and Y. Ozkay, Eur. J. Med. Chem., 2016, 124, 1026-1040.

37 X. Zha, D. Lamba, L. Zhang, Y. Lou, C. Xu, D. Kang, L. Chen, Y. Xu, L. Zhang, A. De Simone, S. Samez, A. Pesaresi, J. Stojan, M. G. Lopez, J. Egea, V. Andrisano and M. Bartolini, J. Med. Chem., 2016, 59, 114-131.

38 C. Zhang, Q. Y. Du, L. D. Chen, W. H. Wu, S. Y. Liao, L. H. Yu and X. T. Liang, Eur. J. Med. Chem., 2016, 116, 200-209.

39 B. Sameem, M. Saeedi, M. Mahdavi and A. Shafiee, Eur. J. Med. Chem., 2017, 128, 332-345.

40 L. Fang, B. Kraus, J. Lehmann, J. Heilmann, Y. Zhang and M. Decker, Bioorg. Med. Chem. Lett., 2008, 18, 2905-2909.

41 Y. Chen, J. Sun, L. Fang, M. Liu, S. Peng, H. Liao, J. Lehmann and Y. Zhang, J. Med. Chem., 2012, 55, 4309-4321.

42 P. R. Carlier, Y. F. Han, E. S. Chow, C. P. Li, H. Wang, T. X. Lieu, H. S. Wong and Y. P. Pang, Bioorg. Med. Chem., 1999, 7, 351-357.

43 G. L. Ellman, K. D. Courtney, V. Andres Jr and R. M. FeatherStone, Biochem. Pharmacol., 1961, 7, 88-95.

44 S. L. Cockroft, C. A. Hunter, K. R. Lawson, J. Perkins and C. J. Urch, J. Am. Chem. Soc., 2005, 127, 8594-8595.

45 C. Quintanova, R. S. Keri, S. M. Marques, M. G. Fernandes, S. M. Cardoso, M. L. Serralheiro and M. A. Santos, MedChemComm, 2015, 6, 1969-1977.

46 G. Wu, D. H. Robertson, C. L. Brooks 3rd and M. Vieth, J. Comput. Chem., 2003, 24, 1549-1562.

47 Y. Chen, X. Xu, T. Fu, W. Li, Z. Liu and H. Sun, RSC Adv., 2015, 5, 90288-90294.

48 M. Bartolini, C. Bertucci, M. L. Bolognesi, A. Cavalli, C. Melchiorre and V. Andrisano, ChemBioChem, 2007, 8, 2152-2161.

49 L. L. Xu, X. Zhang, Z. Y. Jiang and Q. D. You, Bioorg. Med. Chem., 2016, 24, 3540-3547. 